Article

\title{
Feasibility Study of Carbon Dioxide Plume Geothermal Systems in Germany-Utilising Carbon Dioxide for Energy
}

\author{
Kevin McDonnell ${ }^{1,2} \mathbb{D}$, Levente Molnár ${ }^{1, *, \dagger}$, Mary Harty ${ }^{1}$ and Fionnuala Murphy ${ }^{1}$ (D) \\ 1 School of Biosystems and Food Engineering, College of Engineering and Architecture, \\ University College Dublin, Belfield, Dublin 4, Ireland; Kevin.mcdonnell@ucd.ie (K.M.); \\ mary.harty@ucd.ie (M.H.); Fionnuala.Murphy@ucd.ie (F.M.) \\ 2 Biosystems Engineering Ltd., NovaUCD, Belfield, Dublin 4, Ireland \\ * Correspondence: levente.molnar@ucdconnect.ie \\ † Nám. Priatel'stva 2172/33, 92901 Dunajská Streda, Slovakia.
}

Received: 26 March 2020; Accepted: 4 May 2020; Published: 12 May 2020

\begin{abstract}
To manage greenhouse gas emissions, directives on renewable energy usage have been developed by the European Commission with the objective to reduce overall emissions by $40 \%$ by 2030 which presents a significant potential for renewable energy sources. At the same time, it is a challenge for these energy technologies which can only be solved by integrated solutions. Carbon capture and storage combined with geothermal energy could serve as a novel approach to reduce $\mathrm{CO}_{2}$ emissions and at the same time facilitate some of the negative impacts associated with fossil fuel-based power plants. This study focuses on the technical and economic feasibility of combining these technologies based on a published model, data and market research. In the European Union, Germany is the most energy intensive country, and it also has an untapped potential for geothermal energy in the northern as well as the western regions. The $\mathrm{CO}_{2}$ plume geothermal system using supercritical carbon dioxide as the working fluid can be utilized in natural high porosity (10-20\%) and permeability $\left(2.5 \times 10^{-14}-8.4 \times 10^{-16} \mathrm{~m}^{2}\right)$ reservoirs with temperatures as low as $65.8^{\circ} \mathrm{C}$. The feasibility of the project was assessed based on market conditions and policy support in Germany as well as the geologic background of sandstone reservoirs near industrialized areas (Dortmund, Frankfurt) and the possibility of carbon capture integration and $\mathrm{CO}_{2}$ injection. The levelized cost of electricity for a base case results in $€ 0.060 / \mathrm{kWh}$. Optimal system type was assessed in a system optimization model. The project has a potential to supply 6600/12000 households with clean energy (electricity/heat) and sequester carbon dioxide at the same time. A trading scheme for carbon dioxide further expands potential opportunities.
\end{abstract}

Keywords: geothermal; carbon dioxide; sequestration; Germany; coal; carbon capture and utilization

\section{Introduction}

With an increasing concern about global warming, incentives [1,2] have been introduced to reduce greenhouse gas emissions. In the European Union, Directive 2012/27/EU [1] sets target goals by 2020 to increase the share of renewable energy systems by $20 \%$ and reduce greenhouse gas emissions by $20 \%$ compared to 1990 emission levels. However, continuing progress is needed as by 2030 emission levels should be reduced by $40 \%$ and the share of renewable energy in total energy consumption should reach at least $27 \%$ [2]. Member States adopt national plans to cope with the inevitable impacts of climate change [2,3]. Among them, Germany is the biggest energy consumer, while only producing half of its energy needs (Figure 1 [4]). The industry and the public sector are currently dependent on coal power plants, nuclear energy and various fossil fuel (including natural gas) resources. The discrepancy in 
energy supply due to the phase out of nuclear power plants in Germany [5], results in an increase of energy generation from renewables and fossil fuels $[6,7]$.

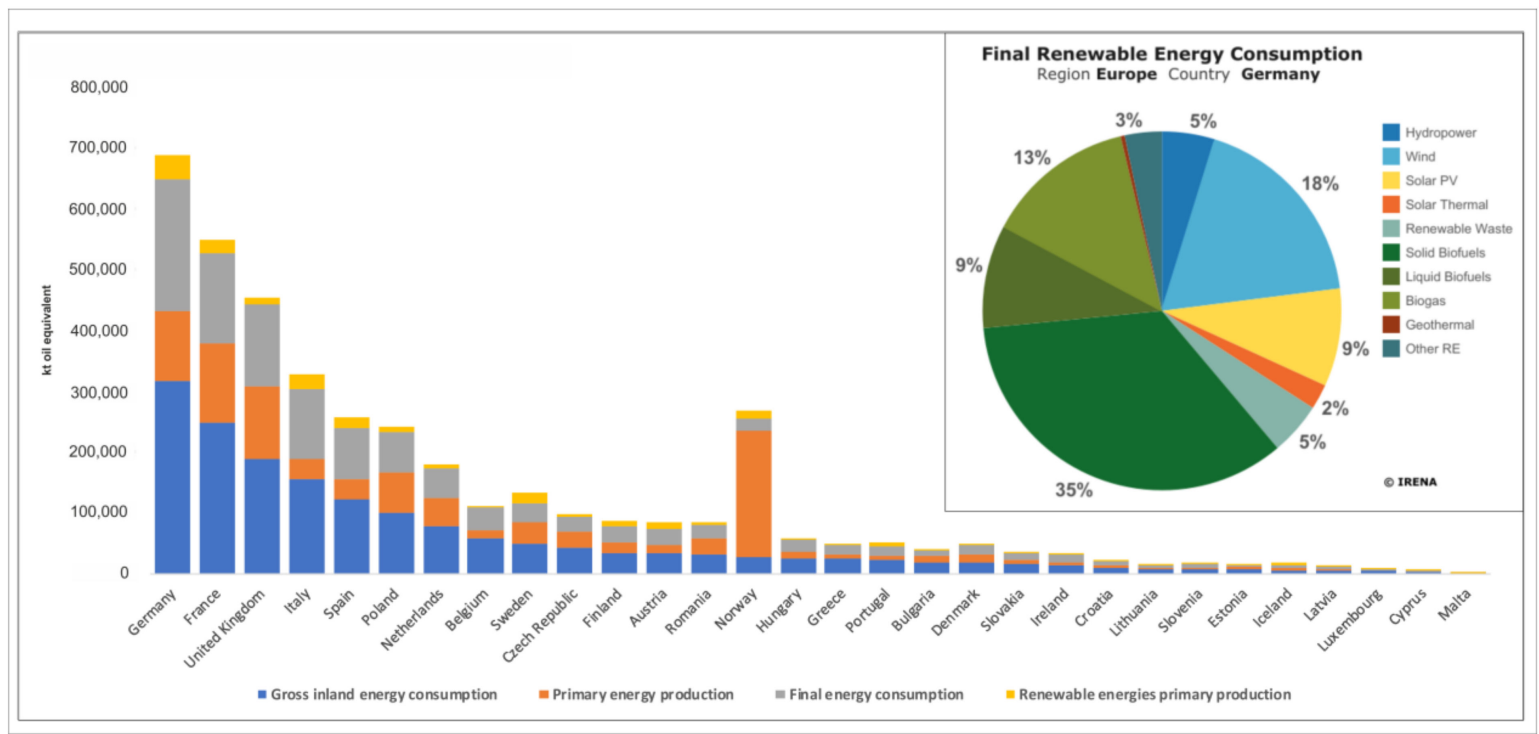

Figure 1. (a) Energy production and consumption in the EU and (b) final renewable energy consumption in Germany $[4,8]$.

In the European Union biomass is the main source of renewable energy followed by wind and solar power. In Germany the main source of renewable energy is from the bio resources (biomass, biogas biodiesel) but wind and solar photovoltaics are representative with $18 \%$ and $9 \%$ respectively (Figure 1. [4]). As of 2016 gross final renewable energy consumption in Germany was below the 18\% target at $14.8 \%$ [4]. While the share of geothermal energy generation is marginal both in the European Union (3.2\%) and Germany (2.5\%), unlike most renewable energy sources it is a viable option in terms of consistent, reliable electricity production without the need for energy storage [4,8]. Capacity factors of geothermal energy are the highest among energy systems above $80 \%$ and even $90 \%$ [9].

Current life cycle assessment and economic studies [10-14] have been carried out for geothermal energy and found to be competitive among renewable energy systems. New techniques have the potential to extract the geothermal heat and sequester carbon dioxide at the same time $[15,16]$. Furthermore, geologic carbon dioxide sequestration has been considered and promoted for reducing anthropogenic $\mathrm{CO}_{2}$ emissions from fossil fuel-based power plants [2,17-19].

Randolph and Saar [20] have investigated and developed a technology to utilize geothermal energy in sedimentary basins where natural high porosity and high permeability reservoirs are present. Instead of water, they modelled the use of supercritical $\mathrm{CO}_{2}$ as the geothermal heat extraction fluid [21]. Due to the better thermodynamic and fluid mechanical properties of $\mathrm{CO}_{2}$ [22-25] it is possible to utilize geothermal energy in areas where temperature of prospective reservoirs are as low as $65.8^{\circ} \mathrm{C}[16,26,27]$.

The Federal Government of Germany has created an opportunity for new projects offering a 20-year feed-in-tariff of $15.0 €$ cents per $\mathrm{kWh}$ for geothermal electricity [3] while promoting and supporting the installation of renewable heat for buildings. Favourable conditions opened up the development of binary cycle geothermal in North Germany, the Upper Rhine Graben from Frankfurt to Basel (Switzerland) and the South German Molasse Basin at the latitude of Munich. As, 55\% of the final energy consumption in Germany is accounted for district heating, hot water and process heat $[28,29]$, the direct use of geothermal energy would supplement the demand for heat especially in the commercial and residential sectors.

Further developments and working geothermal power plants exists in South Germany using heat from the upper Jurassic limestone reservoir [30,31]. In the Upper Rhine Graben favourable conditions are the increased heat flow and higher temperatures. Existing power plants are in Sauerlach, 
Unterhaching, Dürnhaar, Kirchstockach (South Molasse Basin) Insheim, Landau, Bruchsal (Upper Rhine Graben) [32]. Geothermal energy is a mature technology, but carbon capture and storage $[17,18]$ which has been used as an example project $[33,34]$ is still not widely accepted. However, the hydrocarbon industry has long term experience with the transportation and injection of $\mathrm{CO}_{2}$ for enhanced oil recovery (EOR) $[35,36]$. Also, example projects exist to produce coal-bed methane by $\mathrm{CO}_{2}$ injection into coal seams [37].

Conventional $\mathrm{CO}_{2}$ storage is in operation $[34,38]$ at various sites throughout the world. Various research and development phase projects [39-41] are promising and future work could ensure their integration into energy systems. In the EU, large stationary sources ( $>10^{6}$ tons of $\mathrm{CO}_{2} /$ year) emitted $37 \%$ of European global $\mathrm{CO}_{2}$ emissions which is accounted for 337 power plants generating electricity [42,43]. Grid emissions are calculated as $3722 \times 10^{6}$ tons of $\mathrm{CO}_{2}$ /year while the average emissions for coal power plants are $1.04 \mathrm{~g} \mathrm{CO}_{2} / \mathrm{kWh}$ [44]. In case of Germany $81 \%$ of the electricity generated is based on coal [4]. New power plants need to qualify and limit emission levels [43] while older builds may also be suitable to retrofit facilities for $\mathrm{CO}_{2}$ separation $[45,46]$. Power plants could avoid $\mathrm{CO}_{2}$ penalties [47] and be within the emission limits of policies and regulations. Potential sites for the $\mathrm{CO}_{2}$ plume geothermal (CPG) technology exists in the Northern part of Germany in the North East German Basin $[28,48,49]$. The Upper Rhine Graben has a significant potential with sandstone reservoirs and proven geothermal fields [32,50]. However, a number of concerns have to be investigated including seismicity [51,52], $\mathrm{CO}_{2}$ hazards [19,53], Power Plant emissions, pollution levels and land use change [54,55]. Opposition to geothermal energy came from enhanced geothermal systems (EGS) induced seismic events [56]. In Northern Germany the first working EGS Power Plant was located in Landau. An intense monitoring of injection/production ratios and measured seismic events were assessed in the work of Vasterling et al. [56]. Significant seismic events in the area were recorded only historically in 1903 and 1880 [57], while only minor events were recorded during the monitoring $\left(\mathrm{M}_{\mathrm{L}} \leq 2\right)$.

A detailed risk assessment is out of scope of this study, however possible options were investigated and proposed for thorough investigation and periodic inspections. Sites of interest include sandstones in the North East German Basin $[49,58,59]$ and the Upper Rhine Graben $[32,60]$. The most prominent reservoir layer in the North Sea is extending to North Germany [61] where conventional and tight gas fields are indicators of prospective options and the possibility of technology integration for enhanced gas recovery [62,63]. Currently hard coal power plants supply energy along the Datteln-Hamm canal (North Rhine Westphalia, north of Dortmund, Figure 2), from Lünen through Bergkamen to Hamm $[7,64,65]$. The Hayden Power Station and the Mehrum Power Station (Lower Saxony) near Hanover are 920 and 620 MW, respectively, but fossil fuel power stations are located near Frankfurt and surrounding areas as well (Figure 2).

In this study the feasibility of geothermal energy was investigated with the possibility of carbon capture and storage, to serve not only as a renewable source, but to sequester $\mathrm{CO}_{2}$ at the same time. The goal of this study is to investigate the possibility of using the $\mathrm{CO}_{2}$ plume geothermal system in Germany, and to assess the economic feasibility of energy generation and the amount of carbon dioxide sequestration. 


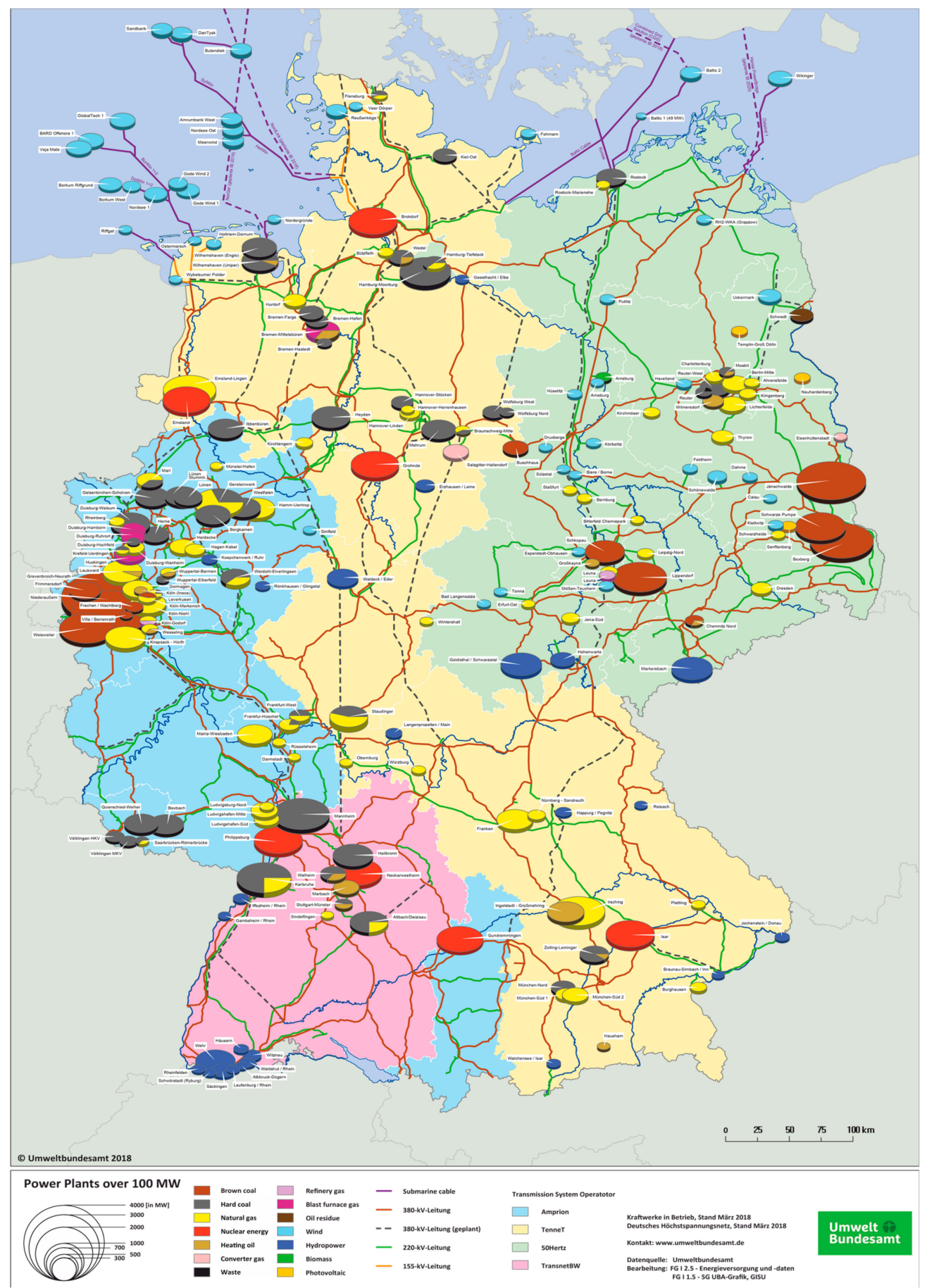

Figure 2. Power plants and transmission network in Germany with power plants over $100 \mathrm{MW}$. Compared to a previous 2008 version nuclear energy was substituted at various locations throughout the country by fossil fuel power plants Reproduced from Federal environmental Agency of Germany 2020 [66].

\section{Data Requirements and Calculation Methods}

Various data requirements, calculation methods and stages of the project were investigated with varying level of interest and accuracy. The integration of the system, the efficiency and the possible energy generation potential is assessed based on researched data and works of Randolph and Saar $[16,20]$. The life cycle of the project is taken as 20 years as currently a feed in tariff for electricity exists in Germany for that time period. It is assumed that the drilling technology is not going to be a 
limiting factor as well as the carbon capture and transportation from the coal power plant. The volume of reservoir is calculated, and the amount of sequestration is expressed as $\mathrm{g} / \mathrm{kWh}$. This makes it possible to compare and expand results with current LCA studies [12,13]. The combination of both technologies, the carbon capture from the flue gas at atmospheric pressures [45] and the geological storage in deep underground reservoirs [34] would join two value and product chains expanding business potential at the same time. Pilot projects are supported by grants, or governmental support. The levelized cost of electricity (LCOE) and return on investment (ROI) are calculated as well as the supply demand scenario e.g. how many households can be supplied by the electricity generated by the CPG system. In case of geothermal energy, the leading example states are Iceland, Italy, New Zealand [67]. Iceland uses its natural resources mainly for district heating saving almost $80 \%$ on other type of resources. Geothermal energy serves as a base load while hydro power takes up the variable load in Iceland's energy network [68]. Italy utilizes hot geothermal fluids to generate electricity [69]. The introduction of new technologies also facilitates the exploitation of deep underground heat for power generation on a wider area [15].

For this feasibility study the project starts with an exploration phase to delineate geological formations suitable for heat extraction and $\mathrm{CO}_{2}$ injection. The CPG system and model is assessed according to Randolph and Saar [16,20]. Naturally high porosity and permeability reservoirs, without the need of well stimulation were researched in Germany and applied for this study. The technology for carbon dioxide capture is assessed based on possible power plant integration and available power plant production and consumption rates. Transportation and injection is based on production and transportation methods, fluid characteristics and safety standards. Economic calculation is based on a spreadsheet model for the specified location, local conditions and market characteristics. A short risk assessment with most probable drawbacks and difficulties are mentioned and treated as a required separate in depth study.

\subsection{Geological Setting}

Proposed sites for harnessing geothermal energy are located in NW Germany. The North East German Basin part of the South Permian Basin is located south of the Trans European Suture Zone [48]. The main targets are sandstone reservoirs like the Rotliegend sandstone extending in the North Sea where it is one of the main reservoirs for hydrocarbon exploration and production [61]. Oil and gas reservoirs hence layers of altered and diagenetically modified sandstones are also targets of interest as well as deep saline aquifers.

In the North German Basin, the movement of Zechstein salts (Late Permian evaporites) resulted in tectonic deformation of Mesozoic and Cenozoic layers. In the Lower Saxony basin at Woitzel quarry Upper Carboniferous outcrops were investigated [49] as analogues to gas and tight gas sandstone reservoirs [50]. Also, the area is well known of intense coal mining of coal seams interbedded with sandstone layers (Figure 3).

The aeolian and fluvial depositional system represents good reservoir characteristics in terms of porosity and permeability [49]. However, diagenetic processes may override initial conditions. Primary porosity in siliciclastic rocks is reduced by compaction of ductile quartz grains, crystal overgrowth formation of clay minerals thus intense illitization [53]. The Upper Carboniferous sandstones were deposited in the NW European Carboniferous Basin, a foredeep NW of the Variscan (Hercynian) orogenic belt [70]. This sub-basin was part of The Central European Basin System formed as a result of Early Mesozoic rifting and wrench tectonics [71-74]. Sub-basins including the Lower Saxony Basin underwent subsidence (sedimentation of sandstones and organic matter) until the Late Cretaceous followed by subsequent inversion $[75,76]$. The Upper Carboniferous (Westphalian) which are the fossil coal bearing sectors represent the main source rock of the natural gas-migrated and trapped-in the reservoirs of the Central European Basin System [77-79]. Production of tight gas deposits has a history of several decades, and the Upper Carboniferous sandstone reservoirs have shown to have continued exploration potential in NW Germany [80]. The Permian Rotliegend sandstone and 
Zechstein carbonates are the main reservoir levels in the region, while Zechstein (Late Permian) evaporites continues to act as a provincial seal across the entire basin for both Carboniferous and Permian reservoirs [78,79]. Stratigraphic layers Similar to the Upper Carboniferous Wesphalian D section are considered among target locations for the present study.

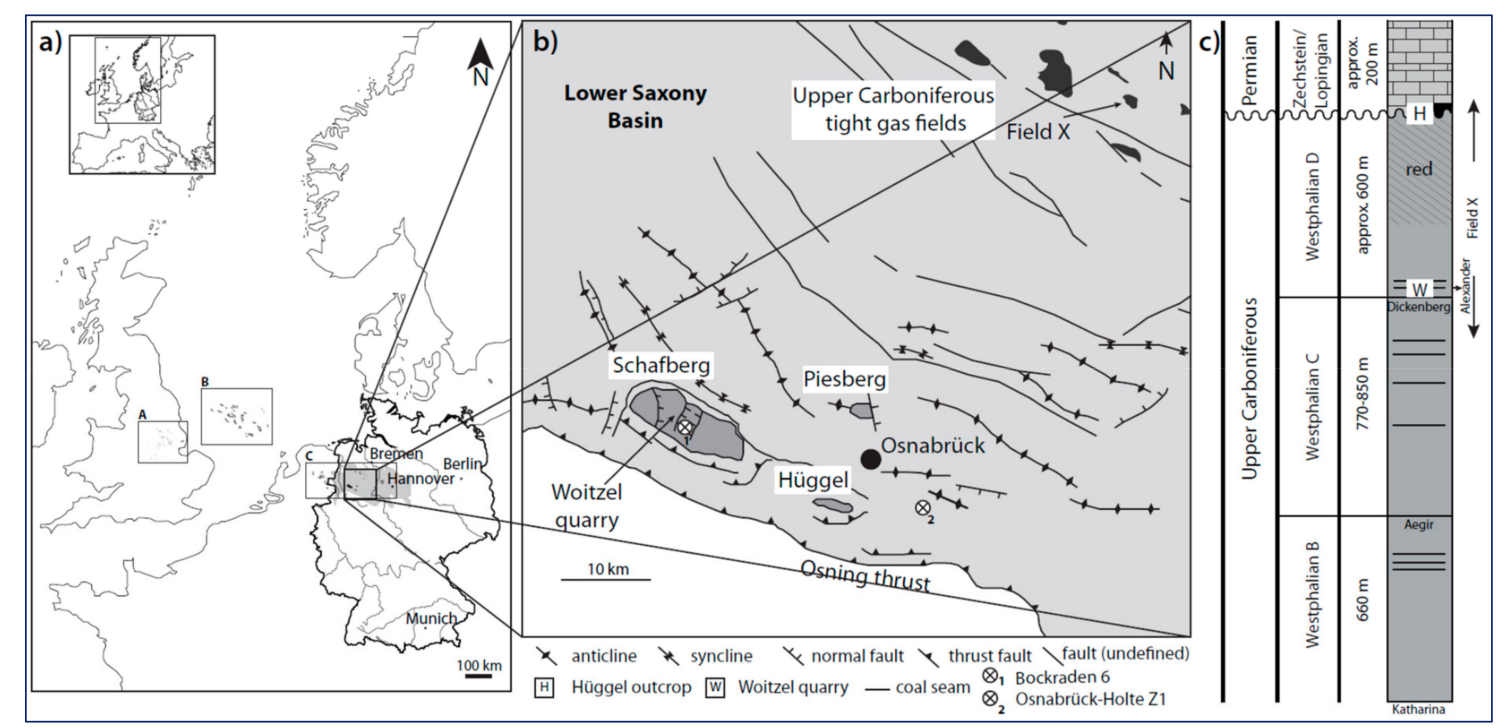

Figure 3. Location map of fields producing from Upper Carboniferous reservoir rocks in NW Europe. (a) A: = onshore UK; B = North Sea, C = onshore Netherlands and Germany. (b) Outline map of the southern and central part of the Lower Saxony Basin showing the locations of Upper Carboniferous outcrops (grey), and of tight gas fields producing from Upper Carboniferous reservoir rocks (black). (c) The Upper Carboniferous to Permian coal bearing stratigraphy (black lines = mineable coal seams) and the stratigraphic positions of the study areas at the Hüggel $(\mathrm{H})$ and Woitzel $(W)$ quarries, together with the position of the reservoir interval at an actual tight gas field ("field X": location in b), are shown in the stratigraphic column.). Reproduced from the Journal of Petroleum Geology 2017 [49].

Similar objects are the oil and gas producing reservoirs in the vicinity of surrounding areas [50]. Research done by Müller et al. [60] concludes a good potential exists in the North Rhine Graben region. Near Frankfurt the reservoir temperatures of the Permocarboniferous sandstones modelled by Arndt et al. [81] and Agemar et al. [82,83] exceed $150{ }^{\circ} \mathrm{C}$. Therefore the potential for electricity generation in association with binary geo-thermal plants is possible and additionally deep geothermal energy is currently utilised in similar settings (Figure 4) in the middle Upper Rhine Graben [32]. In the regions of Landau, Insheim and Bruchsal, the producing basins are cracked crystalline rocks, and fractured sandstones of the Triassic Buntsandstein and the Permocarboniferous. The initial geothermal power plant operating in the siliciclastic and volcanic succession of the Permocarboniferous in the northern Upper Rhine Graben is proposed for Groß-Gerau. The Aeolian sandstones [32] exhibit the highest porosities $(16.4,12.3 \%)$ and permeabilities $\left(2.0 \times 10^{-15}, 8.4 \times 10^{-16} \mathrm{~m}^{2}\right)$, with the average well depth for both regions is in the range of 3000-4000 $\mathrm{m}$ [28]. 


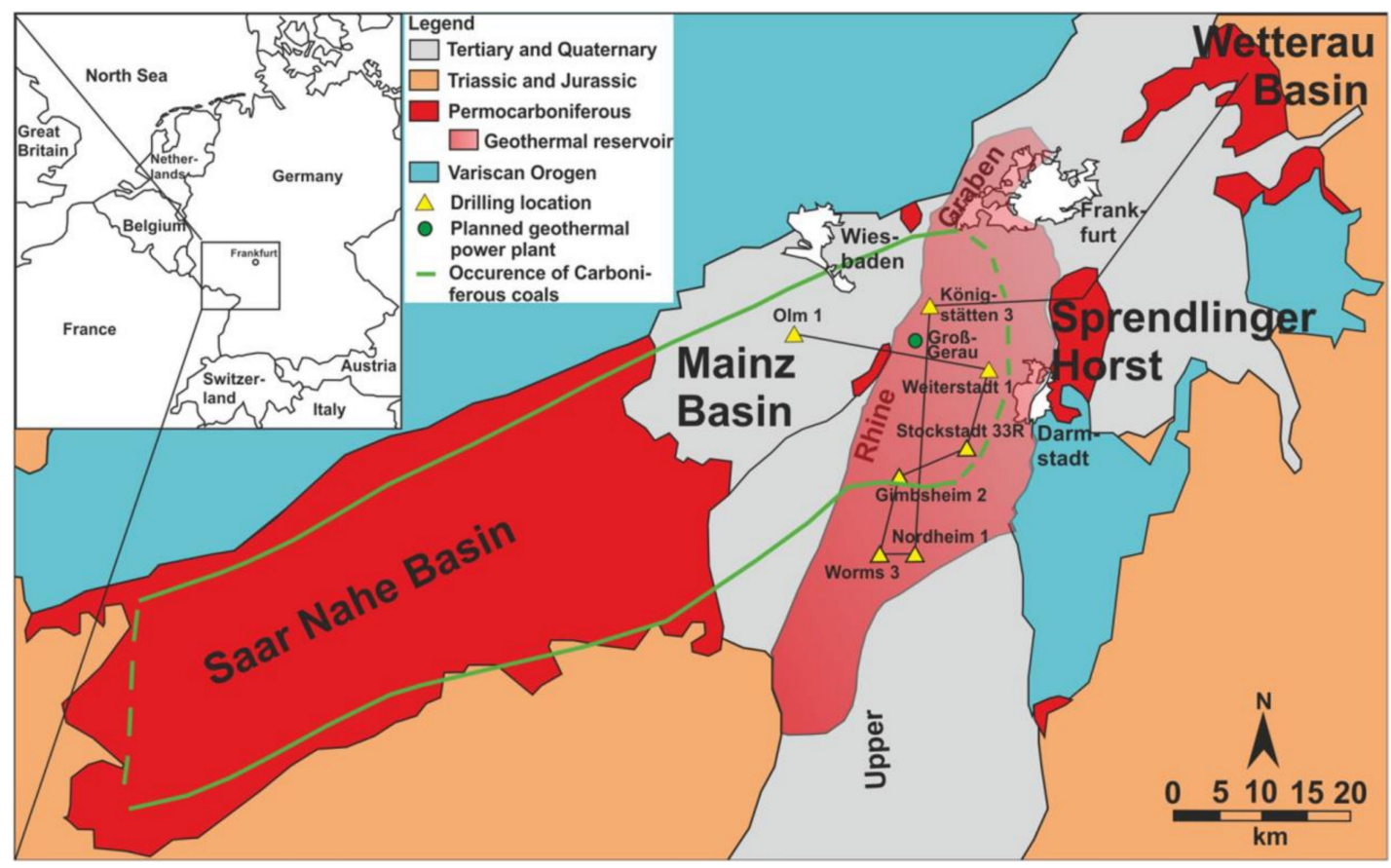

Figure 4. A geological overview map of the Upper Rhine Graben in SW Germany. Modeled reservoir temperatures reach $150{ }^{\circ} \mathrm{C}$. The top of the permocarboniferous reservoir is at $600-2990 \mathrm{~m}$. Reproduced from International Journal of Earth Science 2016 [32]).

\section{2. $\mathrm{CO}_{2}$ Plume Geothermal System (CPG)}

The CPG system described here [20] involves the pumping of supercritical $\mathrm{CO}_{2}$ into natural high porosity and permeability reservoirs described in the previous chapter. The patent which the concept is based on includes the technology and the use of supercritical $\mathrm{CO}_{2}$ for energy generation purposes in the form of electricity or exchanged heat $[84,85]$. The injected $\mathrm{CO}_{2}$ is heated by the geothermal heat flux from Earth's interior. At the production side of the system the $\mathrm{CO}_{2}$ is utilized either for electricity production through a turbine connected to a generator, or in a binary cycle through a heat exchanger to provide energy for electricity generation (binary system), and/or direct use of the thermal energy in district heating systems (Figure 5). In either case the heated carbon dioxide will increase its enthalpy which can be converted through a mechanical system into power or energy. In return carbon dioxide is stored and sequestered for long term in the reservoir. The possibility of a geothermal system coupled with $\mathrm{CO}_{2}$ sequestration has been investigated previously [16,21]. The authors have determined that such a system can provide three times greater heat extraction rates compared to conventional water-based systems [20]. In a steam turbine high pressure high temperature steam is used to power the system. The higher the pressure and temperature the more energy is stored in the steam. At a supercritical state the fluid has both gaseous and liquid like characteristics. In case of water the triggering pressure and temperature are $22.06 \mathrm{MPa}$ and $373.95^{\circ} \mathrm{C}$ [24]. However, $\mathrm{CO}_{2}\left(\mathrm{P}_{\mathrm{cr}}=7.37 \mathrm{MPa}, \mathrm{T}_{\mathrm{cr}}=30.97^{\circ} \mathrm{C}\right)$ has a much lower pressure/temperature ratio, thus limited usage in low temperature systems. A supercritical $\mathrm{CO}_{2}$ power cycle is used to extract energy from a high-pressure low enthalpy reservoir [86]. A numerical simulation is used to assess the available thermal energy. For each case parameters shown in Table 1. (Reservoir parameters based on geological formation; injection/production conditions; initial and boundary condition $[20,32,49]$ are set in a reservoir simulator TOUGH2 (Version 2.0, Lawrence Berkeley National Laboratory, Berkeley, CA, USA) [22] with a supplementary fluid property $\left(\mathrm{CO}_{2}\right.$, water, $\left.\mathrm{NaCl}\right)$ module $\mathrm{ECO} 2 \mathrm{~N}$. The model [20] was constructed as a reference for a five-spot well configuration with $1 \mathrm{~km}^{2}$ map view area and $707 \mathrm{~m}$ between the injection and the production wells. For the model the reservoir thickness was set for $305 \mathrm{~m}$. For the modelled scenario the heat extraction rate was calculated as $47.0 \mathrm{MW}$, averaged over a 
25-year period. The amount of sequestered $\mathrm{CO}_{2}$ is calculated according to the occupiable space in the reservoir. Secondly a natural $5 \%$ fluid loss is expected using $\mathrm{CO}_{2}$ as the working fluid in tight reservoirs. Randolph and Saar [20] are calculating this with a 7\% loss based on the assumption that fluid loss is higher in naturally permeable formations [23]. This means a permanent e.g. non-recoverable $\mathrm{CO}_{2}$ fraction during the operation period of the power plant:

$$
\begin{aligned}
& \mathrm{CO}_{2} \text { loss }=\mathrm{V} * 0.05 * 25 \\
& \mathrm{~V}=\text { Area } * \text { thickness } * \phi
\end{aligned}
$$

where $\mathrm{V}$ is reservoir volume and $\phi$ is the porosity. The total amount of possible sequestration for the whole 20-year lifetime of the project is calculated by the maximum possible occupiable space in the reservoir, the reservoir volume multiplied by the fluid loss over the 20 years. This is then added to the overall $\mathrm{CO}_{2}$ amount in the reservoir.

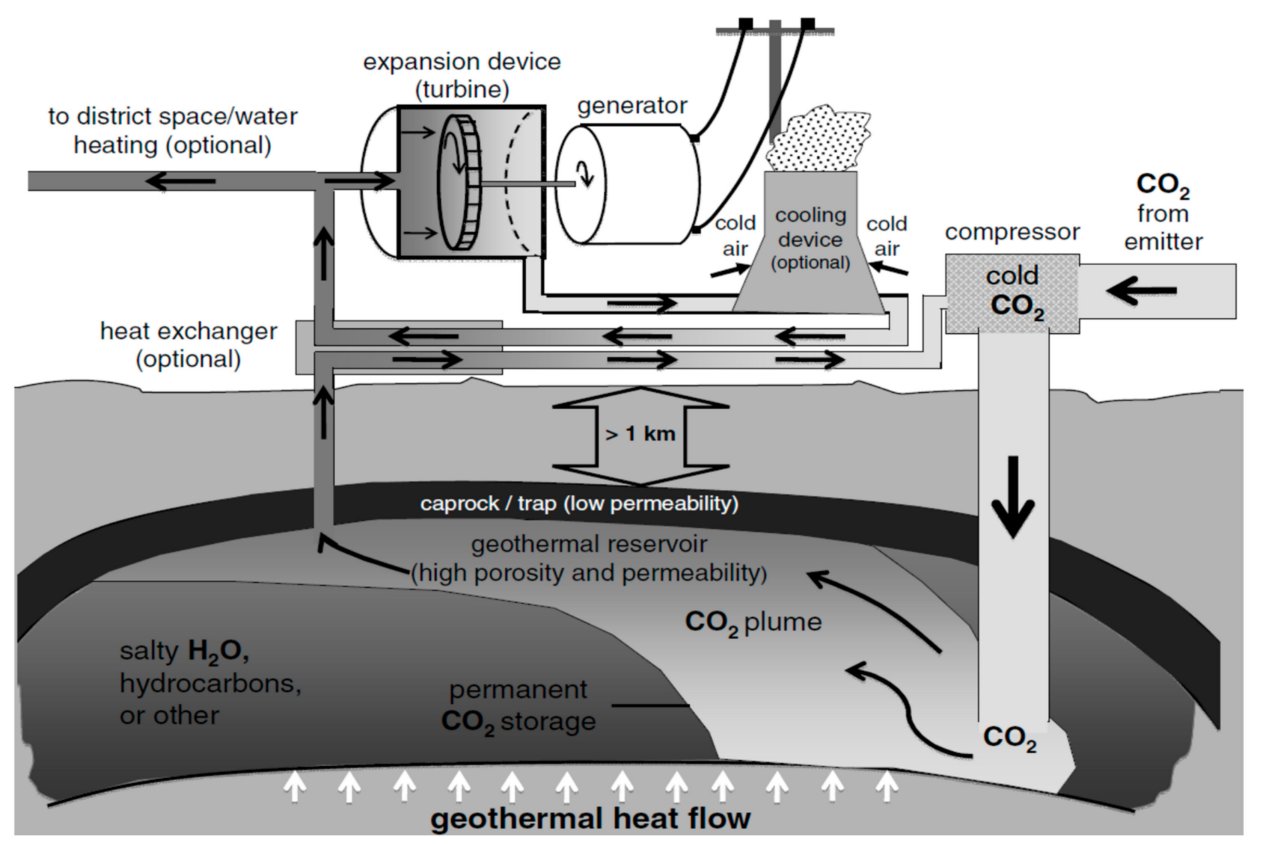

Figure 5. Schematic representation of the $\mathrm{CO}_{2}$ plume geothermal (CPG) system showing the possibility of $\mathrm{CO}_{2}$ sequestration and scenarios with optional elements for electricity production, or district heating systems. The electricity generator is driven by a turbine maintained by the flow of high pressure vaporized $\mathrm{CO}_{2}$ gas. The waste heat can be further utilized through a heat exchanger for district heating or cooling purposes [20].

Table 1. Base case reservoir parameters of the studied geothermal system. Reproduced from Energy

\begin{tabular}{|c|c|c|c|}
\hline \multicolumn{4}{|c|}{ Base Case Parameters } \\
\hline \multicolumn{2}{|c|}{ Geological formation } & \multicolumn{2}{|c|}{ Injection/production conditions } \\
\hline Reservoir area & $3 \mathrm{~km}^{2}$ & Temperature of injected fluid & $15^{\circ} \mathrm{C}$ \\
\hline Thickness & $100 \mathrm{~m}$ & Injection/production rate & max. $300 \mathrm{~kg} / \mathrm{s}$ (variable) \\
\hline Well separation & $707 \mathrm{~m}$ & Injection rate & $126 \mathrm{~kg} / \mathrm{s}$ \\
\hline Permeability & $1.4 \times 10^{-15} \mathrm{~m}^{2}$ & Downhole injection pressure & $31 \mathrm{MPa}$ \\
\hline Porosity & $15 \%(0.15)$ & Downhole production pressure & $30 \mathrm{MPa}$ \\
\hline Rock grain density & $2650 \mathrm{~kg} / \mathrm{m}^{3}$ & Injection duration & 8 years \\
\hline Rock specific heat & $1000 \mathrm{~J} / \mathrm{kg} /{ }^{\circ} \mathrm{C}$ & Production duration & 20-25 years \\
\hline Thermal conductivity & $2.6 \mathrm{~W} / \mathrm{m} / \mathrm{K}$ & & \\
\hline \multicolumn{2}{|c|}{ Formation initial conditions } & \multicolumn{2}{|c|}{ Formation boundary conditions } \\
\hline Fluid in pore spaces & $\mathrm{CO}_{2} / \mathrm{H}_{2} \mathrm{O}$ & Top and sides & No fluid or heat flow \\
\hline Temperature & $130^{\circ} \mathrm{C}$ & Bottom & Heat conduction, no fluid flow \\
\hline Pressure & $30 \mathrm{MPa}$ & & \\
\hline
\end{tabular}
Procedia 2011 with data from Artz et al. 2016 and Becker et al. 2017 [20]. 


\subsection{Carbon Dioxide Capture}

The difference between CPG and a conventional $\mathrm{H}_{2} \mathrm{O}$-based geothermal system is the requirement for the supply of carbon dioxide. Sources of carbon dioxide can be categorized as aerial and stationary, the latter including industrial processes (cement production), fuel combustion (power plants) and natural gas processing. The purpose of the separation process in a power plant is to enable the production of a concentrated stream of $\mathrm{CO}_{2}$ at high pressure, ready for further usage and for transportation and injection into the reservoir [17]. There are two main approaches to capturing the $\mathrm{CO}_{2}$ generated from a fossil fuel power plant and the choice is determined by the technology or plant configuration. In the post-combustion process system, the separation of $\mathrm{CO}_{2}$ from the flue gas produced by the combustion of the primary fuel in air [45], usually use a form of liquid solvents to absorb the low amount of $\mathrm{CO}_{2}$ (typically $3-15 \%$ by volume) contained in the flue gas stream with nitrogen as the main component from air (Figure 6). For current pulverized coal (PC) power plant technologies or for a natural gas combined cycle (NGCC) power plant, the common post-combustion capture systems tend to utilise an organic solvent such as (MEA) monoethanolamine [34,45].

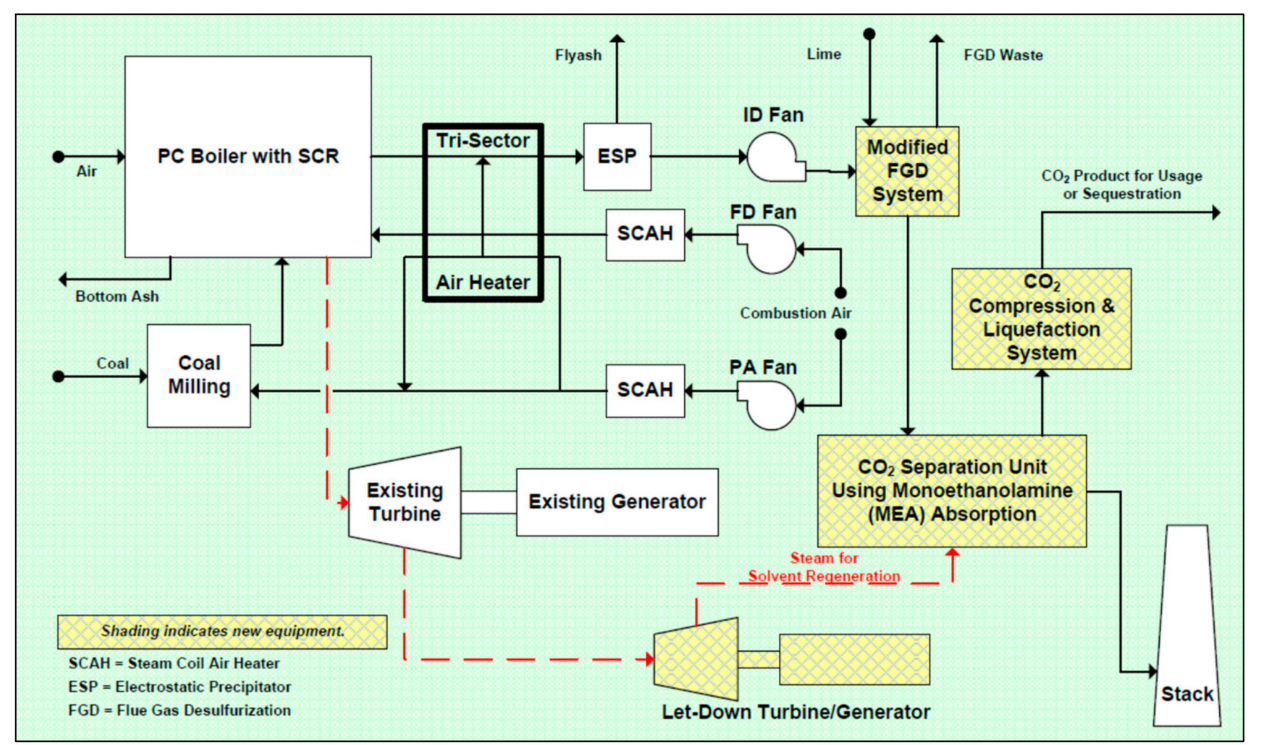

Figure 6. Post combustion capture process for a pulverized coal power plant. The $\mathrm{CO}_{2}$ separation unit using the monoethanolamine absorption process is located before the stack. The amount of captured $\mathrm{CO}_{2}$ is dependent on efficiency factors or desired amounts of $\mathrm{CO}_{2}$. The excess $\mathrm{CO}_{2}$ is then released with the flue gas. Reproduced from NREL 2007 [45].

The exhaust gases from the turbine and the boiler are captured, collected and sent to the separator unit based on MEA absorption. After separation, the $\mathrm{CO}_{2}$ is compressed and liquified, becoming a cool $\left(5{ }^{\circ} \mathrm{C}\right)$ fluid [17]. Pre-combustion is divided into two methods which can be utilised at a system that uses an integrated gasification combined cycle (IGCC) technology. The fossil fuel is used to produce syngas $\left(\mathrm{H}_{2}\right)$ and separates $\mathrm{CO}_{2}$ before combustion. Among them an oxyfuel combustion approach uses oxygen instead of air for ignition of the principal fuel to generate a flue gas that consists primarily of water vapour and $\mathrm{CO}_{2}$. As an approach for $\mathrm{CO}_{2}$ capture in boilers, the oxyfuel technologies are in the validation and demonstration phase [87]. Currently the post-combustion as well as the pre-combustion technologies that are being deployed on generation plants could capture $85-95 \%$ of the $\mathrm{CO}_{2}$ that is generated. While a potentially greater capture efficiencies may be achievable, the required separation equipment is significantly larger, required a higher energy input and is more capital intensive. Further treatment of the flue gas may also be needed to remove air pollutants and non-condensed gases (such as nitrogen) from the flue gas before the $\mathrm{CO}_{2}$ is sent to storage site. Capture and compression roughly need $10-40 \%$ more energy (depending on the type of the system) than the equivalent plant without 
capture technology. The pulverized coal power plant at Lünen operated by Trianel is a modern state of the art power plant with space for carbon capture technology integration [7]. The post combustion capture system based on MEA absorption is capable for a variable $\mathrm{CO}_{2}$ capture ratio based on reservoir size [45]. The capture process includes the compression and liquefaction of the $\mathrm{CO}_{2}$ into $10 \mathrm{MPa}$ which is the standard preparation pressure for transportation [88]. The Lünen power station with 750 MW, $86 \%$ capacity factor and almost $1.5 \times 10^{6} \mathrm{t}$ coal consumption per year produces $4.5 \times 10^{6} \mathrm{tCO}_{2}$ annually [89].

\subsection{Transportation and Injection}

Different transportation methods are optional including truck, rail, ship and pipeline. In this study pipeline transportation is assessed as the most suitable method based on safety concerns. The previously discussed capture method [45] and the distance of the reservoir would involve a pipeline transportation at $0-250 \mathrm{~km}[44,90,91]$. The majority of the worldwide $(6500 \mathrm{~km}) \mathrm{CO}_{2}$ pipelines are linked to EOR, especially in the US [92]. In case of EOR the revenue is made by the increased rate of oil production, which offsets the cost of pipelines. With changing market conditions a project may temporarily shut down while in case of Europe, $\mathrm{CO}_{2}$ storage is viewed as a mitigation option (Table 2). Additionally, pipeline technology used for hydrocarbon transportation could be modified and utilized and where possible underground burying should be assessed regarding safety and alternative options with associated natural landscape interference [17]. The European dedicated standard for $\mathrm{CO}_{2}$ pipeline is: DNV-RP-J202 while an international standard also exists: ISO/TC 265. This study calculates with $400 \mathrm{~mm}$ diameter pipes and investigates different pipeline length to a maximum of $250 \mathrm{~km}$ onshore from source to site. Pressure stations, safety valves and safety signals and signs are planned according to standards and directives of the European Parliament. The method, mode and technology of $\mathrm{CO}_{2}$ injection has been used for decades in the hydrocarbon industry [36]. It is a well-established technology that is used for enhanced oil or gas recovery in mature hydrocarbon fields (Table 3.). Similarly, for the CPG system $\mathrm{CO}_{2}$ is pumped to the reservoir. Based on Soultz Enhanced Geothermal Power Plant the downhole electrical pumping requirement is approximately $100 \mathrm{~kW}_{\mathrm{e}}$ [52]. In case of $\mathrm{CO}_{2}$ instead of water, the larger expansion coefficient generates larger buoyancy forces which results in the net pressure increase between production and injection wells, thus a thermosyphon effect applies which would decrease pumping requirements or can operate without one $[86,93]$. Carbon dioxide in the form of a dense and cool liquid $\left(\rho=950 \mathrm{~kg} / \mathrm{m}^{3}, \mathrm{~T}=5^{\circ} \mathrm{C}\right)$ would sink into the reservoir [94] where conditions of high pressure and temperature $\left(\mathrm{p}=30 \mathrm{MPa} ; \mathrm{T}=130^{\circ} \mathrm{C}\right)$ would transform the $\mathrm{CO}_{2}$ into its supercritical form $\left(\mathrm{p}>7.37 \mathrm{MPa} ; \mathrm{T}>30.97^{\circ} \mathrm{C} ; \rho=560 \mathrm{~kg} / \mathrm{m}^{3}\right)$. For the above-mentioned reasons, the parasitic load of the injection is assumed to be negligible, thus not influencing the net power output of the geothermal power plant.

Table 2. Drivers of $\mathrm{CO}_{2}$ pipeline projects. Reproduced from IEAGHG 2013 [92]).

\begin{tabular}{|c|c|c|}
\hline Motivator & Comments & Example Project \\
\hline Enhanced Oil Recovery (EOR) & $\begin{array}{c}\mathrm{CO}_{2} \text { is used as a tertiary recovery agent to } \\
\text { increase oil production in depleting or } \\
\text { mature oil fields }\end{array}$ & see Table 3. \\
\hline $\mathrm{CO}_{2}$ reduction targets & $\begin{array}{c}\mathrm{CO}_{2} \text { is stored in deep saline formations or } \\
\text { depleted oil or gas fileds }\end{array}$ & see Table 3. \\
\hline $\begin{array}{l}\text { Enhanced Coal Bed Methane } \\
\text { Recovery }\left(\mathrm{CO}_{2} \text {-ECBMR) and }\right. \\
\text { Enhanced Gas Recovery (EGR) }\end{array}$ & $\begin{array}{l}\mathrm{CO}_{2} \text { is used to enhance coal bed methane } \\
\text { production from coal-beds or coal bearing } \\
\text { formations or re-injected in suitable gas } \\
\text { formations (depleted or for EGR) }\end{array}$ & see Table 3. \\
\hline Use of $\mathrm{CO}_{2}$ for industrial purposes & $\begin{array}{l}\mathrm{CO}_{2} \text { is transported to greenhouses and used } \\
\text { to stimulate growth of plants and crops }\end{array}$ & OCAP, Netherlands \\
\hline
\end{tabular}


Table 3. Worldwide $\mathrm{CO}_{2}$ utilization sites for enhanced oil recovery (EOR), $\mathrm{CO}_{2}$-enhanced coalbed methane $\left(\mathrm{CO}_{2}\right.$-ECBM) and $\mathrm{CO}_{2}$ storage. Reproduced from Renewable \& Sustainable Energy Reviews 2014 [34].

\begin{tabular}{ccccc}
\hline Project Name & Type & Location & Start Year & $\begin{array}{c}\text { Max. CO } \text { Injection } \\
\text { Rate (t/Year) }\end{array}$ \\
\hline Jilin oil filed & EOR & Jilin, China & 100,000 \\
Weyburn-Midale & EOR & Saskatchewan, Canada & 2000 & $2,200,000$ \\
Paradox Basin & EOR & Utah, USA & 2005 & 140,000 \\
Salt Creek & EOR & Wyoming, USA & 2006 & $2,200,000$ \\
Williston Basin & EOR & North Dakota, USA & 2011 & $1,000,000$ \\
South Heart & EOR & North Dakota, USA & 2012 & 600,000 \\
Oologah & EOR & Oklahoma, USA & 2012 & $1,500,000$ \\
Masdar & EOR & Abu Dhabi, United Arab Emirates & 2012 & $1,700,000$ \\
Hatfield & EOR & Hatfield, UK. & 2013 & $6,500,000$ \\
California (DF2) & EOR & California, USA & 2014 & $5,000,000$ \\
Mongstad & EOR & Mongstad, Norway & 2014 & $1,500,000$ \\
Trailblazer & EOR & Texas, USA & 2014 & $4,300,000$ \\
Greengen & EOR & China & 2015 & 700,000 \\
Genesee (EPCOR) & EOR & Alberta, Canada & 2015 & $3,600,000$ \\
San Juan Basin & $\mathrm{CO}_{2}$-ECBM & New Mwxico, USA & 1996 & 100,000 \\
Permian Basin & $\mathrm{CO}_{2}$-ECBM & Texas, USA & 2005 & 300,000 \\
Farnham & $\mathrm{CO}_{2}$-ECBM & Utah, USA & 2005 & 900,000 \\
Dome/Uinta Basin & $\mathrm{CO}_{2}$ storage & Alberta \& B.C., Canada & 1990 & 100,000 \\
Alberta Basin & $\mathrm{CO}_{2}$ storage & West Virginia, USA & 2009 & 100,000 \\
Mountaineer & $\mathrm{CO}_{2}$ storage & Italy & 2012 & $1,200,000$ \\
Brindisi & $\mathrm{CO}_{2}$ storage & North sea, Norway & 1996 & $1,000,000$ \\
Sleipner & $\mathrm{CO}_{2}$ storage & Barents sea, Norway & 2008 & 700,000 \\
SnØhvit & $\mathrm{CO}_{2}$ storage & Victoria, Australia & 2015 & $13,000,000$ \\
Latrobe Valley & & & & \\
\hline
\end{tabular}

\subsection{Economic Calculation}

For the economic model the carbon capture technology with the compression and liquefaction stage together with the transportation through pipelines were assessed. An average $32 € / \mathrm{tCO}_{2}$ capture price was accepted based on Ramezan et al. [45] and an IPCC report [17]. The cost of transportation based on Morbee et al. [91] for a reference case is between 1.7-3.5 $€ / t$. Haumann et al. [88] have investigated a pipeline route from Germany to Algeria through Sardinia (Italy). The cost of pipeline transport for their model was normalized as $11.3-13.7 € / \mathrm{t}$. Their calculation included a section across the Mediterranean Sea, which translates to increased overall costs. A recent study by d'Amore and Bezzo [44] indicates a unitary pipeline transportation cost of $0.04009 € / \mathrm{t} \mathrm{CO} / 2 \mathrm{~km}$ under 1 million tonnes of $\mathrm{CO}_{2}$ transported per year. In case of 5 million tonnes of $\mathrm{CO}_{2}$ annually, the pipeline transportation cost decreases to $0.01476 € / \mathrm{t} \mathrm{CO} / \mathrm{km}$. As a rule, the cost of $\mathrm{CO}_{2}$ transported through the pipeline decreases with increasing amount of $\mathrm{CO}_{2}$. A different study by Heddle et al. [90] calculates with $1.5-2 \$ /$ ton of $\mathrm{CO}_{2} / 100 \mathrm{~km}$. The initial phase of the project the exploration phase is planned for four years for the exploration drilling and testing period (including licensing and permission). After an initial investigation a 3D seismic survey have to be measured for further exploration and delineation of possible prospects [30]. The measurement and the processing periods are taken to be 6 months. The seismic interpretation and the mapping of the reservoirs is considered feasible within an 18-month period. The planned steps are a small 3D seismic reflection survey to explore facies and geological structures, regional geological 3D modelling of structures aided by additional existing 2D seismic profiles, hydrogeological modelling, and numerical simulation of fluid flow, heat transfer and corresponding forecasting [30]. Another 6 months is considered for reservoir simulation before the drilling period. The cost of drilling of a geothermal well is based on hydrocarbon and hydrogeological well costs. Based on Kipsang [95] the drilling of a 3000 m geothermal well costs 5.8 million \$. A different 
study from Lukawski et al. [96] is calculating the cost (million US dollars) of a geothermal well based on statistical analysis of hydrocarbon and geothermal well cost trends.

$$
\text { Geothermal well cost }=1.72 * 10^{-7 *} \mathbf{M D}^{2}+2.3^{*} 10^{-3 *} \mathbf{M D}-0.62
$$

where MD is the measured depth of the geothermal well. In case of this study two $3000 \mathrm{~m}$ wells were calculated with one for injection and one for production. A possibility of a reuse and modification of a hydrocarbon well would significantly decrease capital cost requirement but would not necessarily mean less construction time. North Germany hosts hydrocarbon fields including natural gas reservoirs. If carbon dioxide is used for enhanced hydrocarbon recovery, the revenue price of the net produced oil, natural gas or methane could be accounted as an additional product. The cost of the power plant including a high-pressure turbine, heat exchanger reinjection unit with a control station and safety measures is taken from Stefansson [68]. The study calculates with $977 \$ / \mathrm{kW}$ for the surface equipment costs for power plants in the range of 20-60 MW. To mitigate investment costs and efficiency loss a study by Wang et al. [97] investigates geothermal energy integration with a post-combustion $300 \mathrm{MW}_{\mathrm{e}}$ coal fired power plant. The renewable heat fraction is used for the sorbent regeneration in the capture process. In case of a CPG system this means that part of the heat could be utilized regardless of consumer demand thus decreasing the energy used for the capture process. The capacity factor in case of a geothermal power station is actually an operator choice. After the initial reservoir fill up of circa 10\% according to Randolph and Saar [20], the reservoir can produce work continuously if desired. With proper planning, only minimal maintenance is required, which is calculated as Operation and Maintenance, $3 \times 7 \times 24 \mathrm{~h} /$ year. Stefansson [68] indicates an $8000 \mathrm{~h} /$ year operation for average geothermal power plants in Iceland. The possibility for governmental support in form of grants and funds are calculated in the present study. The amount is assumed to cover exploration costs. Exploration costs includes data room, data acquisition, data processing, 3D survey measurement and processing as well as interpretation. Data is based on Clauser and Ewert [98] and includes software and labour for the exploration and drilling cost of one well. Several organisations offer favourable conditions for investments and pilot/demonstration projects. A study by Weber et al. [28] indicates an overall sum of $€ 20.6$ million in awarded grants for 20 geothermal projects. Averaged over projects it translates to $€ 1$ million per project. The government of Germany [3], offered a $15 \mathrm{cent} / \mathrm{kWh}$ feed in tariff for 20 years. This means the selling price of the generated electricity is granted and the profit/investment ratio will determine the ROI and the break-even point expressed as $\%$ and years. The LCOE is based on the electricity generation potential/total life cycle cost. It is assumed that all the electricity generated is sold back or is required hence the demand for electricity is not a limiting factor. In case of the utilization of geothermal heat, the supply is calculated based on the heat recovery ratio of the heat exchanger. A continuous supply is possible, but the actual demand (district heating, greenhouses) sets a limit to the useful heat energy. In this study the district heating system is outside of the system boundary, while the geothermal heat is calculated based on average heating days multiplied by the average heat usage of a household in Germany [4]. To summarize, the available supply of households is calculated. The price of thermal energy was based on a study by Routledge and Williams [29]. They estimated an average $4 €$ cent $/ \mathrm{kWh}$ consumer price for the supplied equivalent thermal energy. In contrast, the price estimate of gas burned in boilers to produce hot water was $5 €$ cent $/ \mathrm{kWh}$. Prices reflect UK market (prices converted to Euro on Q2 $2018 £-€$ conversion rates) and it is assumed that the scenario will effectively describe the German household heat market as well. The system is assessed and fine-tuned in an optimization model by HOMER Energy (Homer Pro 2018). The optimal system is graphed based on sensitivity analysis of parameters (cost of electricity, sellback rate, $\mathrm{CO}_{2}$ price). The model is used to assess renewable energy systems and while geothermal energy is a special case it is simulated as a generator with $\mathrm{CO}_{2}$ as the fuel. Parameters of the $\mathrm{CO}_{2}$ like the heating value and density at reservoir conditions are given based on Pioro and Mokry [24] as well as Randolph and Saar [16] and Saar et al. [84,85]. 


\section{Risk Assessment}

Every project is presented with a specific amount of risk. In case of geothermal energy, and CPG system in general the associated risks are the success of the exploration and drilling of the production and injection wells. To mitigate risk and increase success rate a geological risk analysis is conducted. Other risks include environmental $\mathrm{CO}_{2}$ hazards due to leakage from transportation, leakage of the $\mathrm{CO}_{2}$ from the well and the reservoir through various routes [17,53]. In case of EGS in Germany, the first power plant in Landau [56] and a second one at Soultz EGS reservoir [52] was extensively monitored for induced seismicity. Injection rates were determined safe from 20 to $80 \mathrm{~kg} / \mathrm{s}$ (L/s). According to Directive 2011/92/EU of the European Parliament [99], an environmental impact assessment (EIA) is required for projects with increased potential of landscape change. In case of this report the buried depth, the accessibility, installation of safety valves to isolate faulty sections, failure and corrosion prevention both in and outside of pipe wall are the required cases that have to be assessed. Apart from risks concerning the environment risk involving economic uncertainties also exists. These including electricity prices, change in feed-in-tariffs, change in policy and legislations. Public perception on various projects is not negligible and often moving forward into implementation phase fails because of inadequate information and involvement of public and the society.

\section{Results and Discussion}

The objective of this paper was to locate a potential site for the installation of the $\mathrm{CO}_{2}$ plume geothermal system. Parameters for the reservoir simulation have to be further researched but based on Randolph and Saar [2] as well as Weber et al. [28] calculations were performed for natural high porosity and permeability formations existing in northern and western Germany. The support of geothermal energy is favourable in Germany as a feed-in tariff exists for a 20-year period. Additionally, the cost of drilling and construction of the power plant will be offset by the $\mathrm{CO}_{2}$ sequestration as an additional layer to the renewable energy generation facilitating an existing fossil fuel-based power plant as the source of $\mathrm{CO}_{2}$ as well. In case of this study the source of $\mathrm{CO}_{2}$ was chosen to be from the Lünen Pulverized coal power plant operated by the company Trianel. Currently regulations calculate with $€ 40 / t$ carbon dioxide emission penalty [47]. If that was to apply for the emitted $\mathrm{CO}_{2}$ by the coal power plant, the cost would be in the range of $€ 180^{*} 10^{6}$. However, a $€ 100$ penalty $\left(€ 450 \times 10^{6}\right)$ is proposed to be applied in the future therefore, the power plant was constructed with possible carbon capture and storage integration. For this reason and considering the carbon penalty, the capital investments associated with the separation and capture technology is accounted for the coal power plant. In the case of a post combustion process the technology includes the absorption unit, the regenerator unit, compressor and possible storage tanks. The total capture cost per tonne of $\mathrm{CO}_{2}$ was based on Ramezan et al. [45], using costs of $€ 32 / \mathrm{t} \mathrm{CO}$ price. The cost of capture is $€ 116 \times 10^{6}$ with pipeline transportation as the safest solution to transport large amounts of liquid $\mathrm{CO}_{2}$. In case of the Lünen power plant the possible amount of $\mathrm{CO}_{2}$ after capture and compression is $3.9 \times 10^{6}$ tons of $\mathrm{CO}_{2} /$ year. This value falls within a range of current injection rates to enhanced oil recovery, coalbed methane and $\mathrm{CO}_{2}$ storage sites. A $100 \mathrm{~km}$ radius delineating a pipeline transportation area is illustrated on Figure 7. The calculated price of the transportation of the amount of $\mathrm{CO}_{2}$ from the coal power plant at a distance to $100 \mathrm{~km}$ is $€ 7.3 \times 10^{6}$. If possible a shorter distance route of $0-50 \mathrm{~km}$ is preferred for lower costs and less permitting issues. A range of $20 \mathrm{~km}$ would cover the populated area around power plants. This case also represents power stations closer to $\mathrm{CO}_{2}$ utilization sites. The possibility of long term usage of the pipelines requires an extensive $\mathrm{CO}_{2}$ pipeline network from and around major fossil fuel power plants. A pipeline network from source to $250 \mathrm{~km}$ with Lünen power station as the source (Figure 7) correlates well with the location of major power stations and possible reservoir sites. The geothermal well cost was based on statistical well cost analysis. For a $3000 \mathrm{~m}$ geothermal well the current study calculates a cost of $€ 6.6 \times 10^{6}$. Exploration costs are based on Clauser and Ewert [98] as $€ 1.3 \times 10^{6}$. The cost of constructing a $50 \mathrm{MW}$ geothermal power plant with the machinery is predicted as $€ 42 \times 10^{6}$. The total project cost with power plant machinery and construction excluding the pipelines was calculated as 
$€ 54.1 \times 10^{6}$. This project has calculated the reservoir potential based on previous studies and reservoir characteristics of sandstones in the North German Basin as well as the North Upper Rhine Graben. Based on simulations in works of Randolph and Saar [16], Garapati et al. [21] an analogy was drawn to the present study which calculates with the power generation potential of $50 \mathrm{MW}$. The electricity generation potential is calculated by multiplying the gross thermal output with the Carnot efficiency and the turbine mechanical efficiency. In case of the studied sites the reservoir temperature is set as $130{ }^{\circ} \mathrm{C}(403 \mathrm{~K})$ while the average ambient outside temperature is taken as $15^{\circ} \mathrm{C}(288 \mathrm{~K})$. This gives a Carnot efficiency of 0.29 . The system utilization efficiency of the turbine was set to 0.45 , while the heat recovery ratio is calculated as $55 \%$. The calculated electricity generation potential is $6.5 \mathrm{MW}_{\mathrm{e}}$, while the thermal output potential is $24 \mathrm{MW}_{\mathrm{th}}$. The annual electricity generation potential with a $94 \%$ capacity factor is $52,850 \mathrm{MWh}$ (Table 4 ). Calculating with a fixed $€ 0.15 / \mathrm{kWh}$ feed-in-tariff for geothermal electricity the LCOE for a base case is $€ 0.059 / \mathrm{kWh}$ which includes the exploration, drilling, power plant construction and operation costs (case 1). The pipeline transportation cost to a distance of $100 \mathrm{~km}$ if accounted in the geothermal power plant (case 2) increases the levelized cost of electricity to $€ 0.107 / \mathrm{kWh}$. Based on gathered and calculated data the model was expanded into the HOMER Pro optimization model (Version 3.13, Homer Energy LLC, Bolder, CO, USA) to test sensitivities and determine optimal system type. Values for electricity prices were tested in the range of $€ 0.0-0.3 / \mathrm{kWh}$ while a lower feed-in-tariff and zero value was also investigated. Carbon dioxide as a fuel was added to the model and the price $(€ / \mathrm{kg})$ was converted as pipeline costs. The primary electrical and thermal load was added based on the previous calculations; hence a system was built where the supply demand scenario is more or less the same. Furthermore, the real and nominal interest rates for Germany in 2018 were incorporated to the model as $-1.91 \%$ and $0.0 \%$. Results of the sensitivity analysis and optimal system are shown on Figure 8. For case 1 the HOMER model resulted in $€ 0.060 / \mathrm{kWh}$ while case 2 with a $100 \mathrm{~km}$ pipeline cost would give $€ 0.093 / \mathrm{kWh}$. Both cases represent a $94 \%$ geothermal capacity factor serving as base load. The return on investment is $21.5 \%$ for case 1 and $18 \%$ for case 2 while the simple payback time was calculated as 3.8 and 4.3 years, respectively. In Figure 9, subfigures (c) and (d) represent an incorporated pipeline cost to $250 \mathrm{~km}$ and $400 \mathrm{~km}$ as still being feasible under certain conditions like electricity price and sellback rate. In case of utilising the carbon capture technology the LCOE of the coal power plant increases by $36 \%$. Data and calculated values correlate well with recent studies [98,100]. Figure 9 compares the levelized cost of electricity from various renewable energy sources. Compared to geothermal energy solar PV is the most variable in terms of price $/ \mathrm{kWh}$ but wind energy is considerably more capital intensive as well. While biomass derived, energy is comparable with geothermal energy it has significantly higher impact in terms of land use change, GHG emissions (Figure 10) and possible air pollution $\left(\mathrm{PM}_{2.5}\right)$. The high variability between energy sources in energy price/ $\mathrm{kWh}$ could be interpreted as lack of legislative support or funds for the installation of the power plants as well as local conditions. Geothermal energy is still among the cheapest and most reliable sources of energy, competitive with fossil fuel power plants.

Table 4. Parameters of the components and capital cost requirements of deploying the system.

\begin{tabular}{cccc}
\hline Parameters & Value & Unit & Reference \\
\hline Lifetime & 20 & years & \\
Germany electricity price & 30 & $€ / \mathrm{MWh}$ & \\
Sellback rate & 20 & $€ / \mathrm{MWh}$ & {$[3]$} \\
Pulverized Coal Power Plant & & $\mathrm{MW}$ & {$[89]$} \\
PP size & 750 & $\mathrm{~h} /$ year & \\
Operation & 7800 & $\mathrm{kWh} /$ year & \\
Production & $5,850,000,000$ & $\mathrm{t} /$ year & \\
Coal consumption & $1,500,000$ & $\mathrm{\epsilon} / \mathrm{t}$ & \\
Coal price & 93.5 & $\mathrm{t} /$ year & \\
$\mathrm{CO}_{2}$ amount & $4,500,000$ & $\mathrm{o}$ & {$[45]$} \\
$\mathrm{Capture} \mathrm{Ratio}_{\mathrm{CO}_{2} \text { to Capture }}$ & 90 & $\mathrm{t} /$ year & \\
\hline
\end{tabular}


Table 4. Cont.

\begin{tabular}{|c|c|c|c|}
\hline Parameters & Value & Unit & Reference \\
\hline $\mathrm{CO}_{2}$ emitted (calculated) & 0.769230769 & $\mathrm{~kg} \mathrm{CO}_{2} / \mathrm{kWh}$ & \\
\hline $\mathrm{CO}_{2}$ emitted (reference) & 0.75 & $\mathrm{~kg} \mathrm{CO} / \mathrm{kWh}$ & {$[43,89]$} \\
\hline Power Plant cost & $1,400,000,000$ & $€$ & [89] \\
\hline Operation and Maintenance & $140,250,000$ & $€ /$ year & \\
\hline $\mathrm{CO}_{2}$ penalty & 100 & $€ / \mathrm{tCO}_{2}$ & [47] \\
\hline $\mathrm{CO}_{2}$ penalty & $450,000,000$ & $€ /$ year & \\
\hline Capture cost & 32 & $€ / \mathrm{tCO}_{2}$ & [45] \\
\hline Total Capture cost & $116,640,000$ & $€ /$ year & \\
\hline \multicolumn{4}{|l|}{ Pipeline } \\
\hline Length & 100 & $\mathrm{~km}$ & \\
\hline Transportation capacity & 50 & 106 t/year & [88] \\
\hline Transportation cost & 0.02 & $€ / \mathrm{tCO} / \mathrm{km}$ & [44] \\
\hline Transportation cost & $7,290,000$ & $€ /$ year & [44] \\
\hline \multicolumn{4}{|l|}{ Exploration and drilling } \\
\hline Drilling cost & $6,653,800$ & $€$ & [96] \\
\hline Exploration cost & $1,330,760$ & $€$ & [98] \\
\hline Number of wells & 2 & & \\
\hline Exploration and drilling cost & $14,638,360$ & $€$ & [96] \\
\hline \multicolumn{4}{|l|}{ Reservoir } \\
\hline Depth & 3000 & $\mathrm{~m}$ & {$[32,49]$} \\
\hline Temperature & 130 & ${ }^{\circ} \mathrm{C}$ & {$[32,49]$} \\
\hline Area & 3 & $\mathrm{~km}^{2}$ & {$[32,49]$} \\
\hline Thickness & 100 & $\mathrm{~m}$ & {$[32,49]$} \\
\hline Volume & 0.3 & $\mathrm{~km}^{3}$ & \\
\hline $\mathrm{CO} 2$ density & 560 & $\mathrm{~kg} / \mathrm{m}^{3}$ & [24] \\
\hline Fluid loss & 5 & $\%$ & [22] \\
\hline \multicolumn{4}{|l|}{ Geothermal Power Plant } \\
\hline Size & 50 & MW & {$[16,20]$} \\
\hline Electricity output & 6.5 & MW & {$[16,20]$} \\
\hline Thermal output & 28 & MW & {$[16,20]$} \\
\hline Electricity Generation (potential) & 56,200 & MWh/year & \\
\hline Thermal energy generation (potential) & 248,000 & MWh/year & \\
\hline Construction and machinery & $41,522,500$ & $€$ & [68] \\
\hline Operation and Maintenance & 504 & $\mathrm{~h}$ & [68] \\
\hline \multirow[t]{2}{*}{$\mathrm{O} \& \mathrm{M}$} & 800 & $€ / \mathrm{h}$ & \\
\hline & 403,200 & $€ /$ year & [68] \\
\hline Grants & $2,000,000$ & $€$ & {$[3,28]$} \\
\hline TOTAL PROJECT COST & $54,160,860$ & $€$ & \\
\hline
\end{tabular}

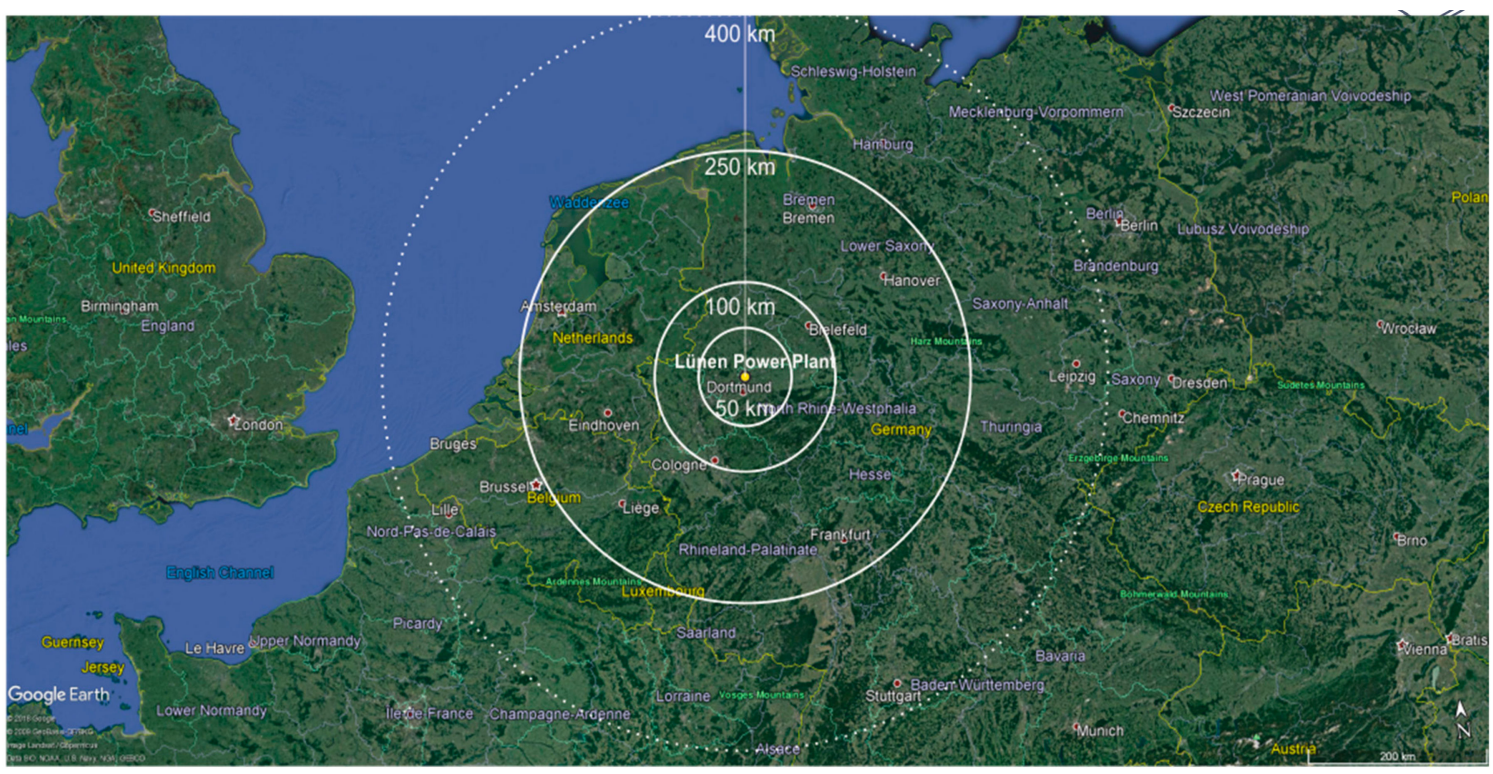

Figure 7. Illustration of pipeline length and reachable distance up to $400 \mathrm{~km}$. 

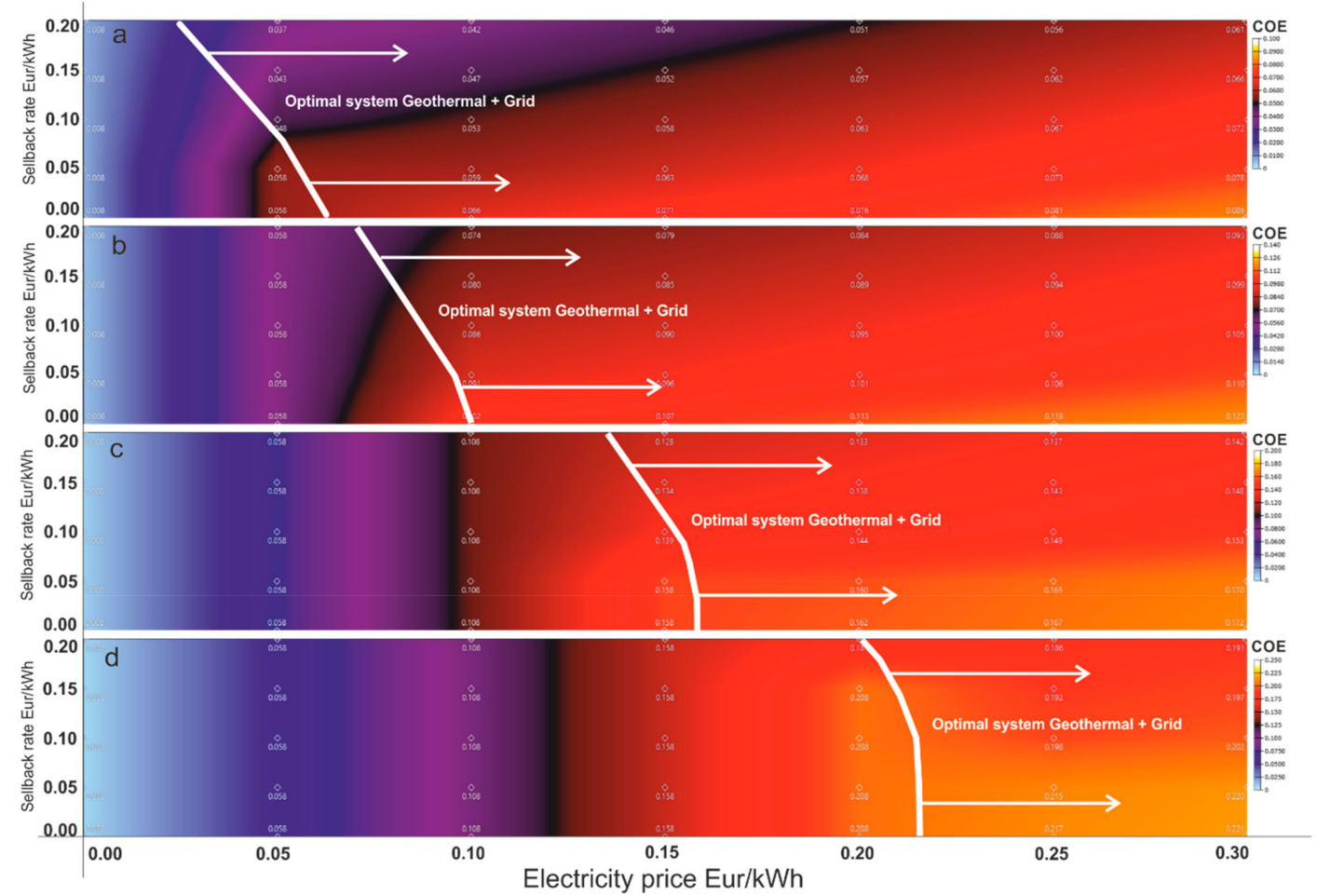

Figure 8. Sensitivity analysis and optimal system based on HOMER Pro. Pipeline costs were calculated for case 1 (a) and case 2 (b) while a third case (c) represents the optimal system type with $250 \mathrm{~km}$ pipelines. Case 4 (d) was calculated as the highest distance of pipelines $(400 \mathrm{~km})$ where the project is still feasible with $€ 0.3 / \mathrm{kWh}$ electricity prices and $€ 0.0 / \mathrm{kWh}$ REFIT. Project life was set for 20 years as a REFIT scheme is offered for that time period.

Global levelised cost of electricity from utility-scale renewable power generation technologies 2010 - 2017

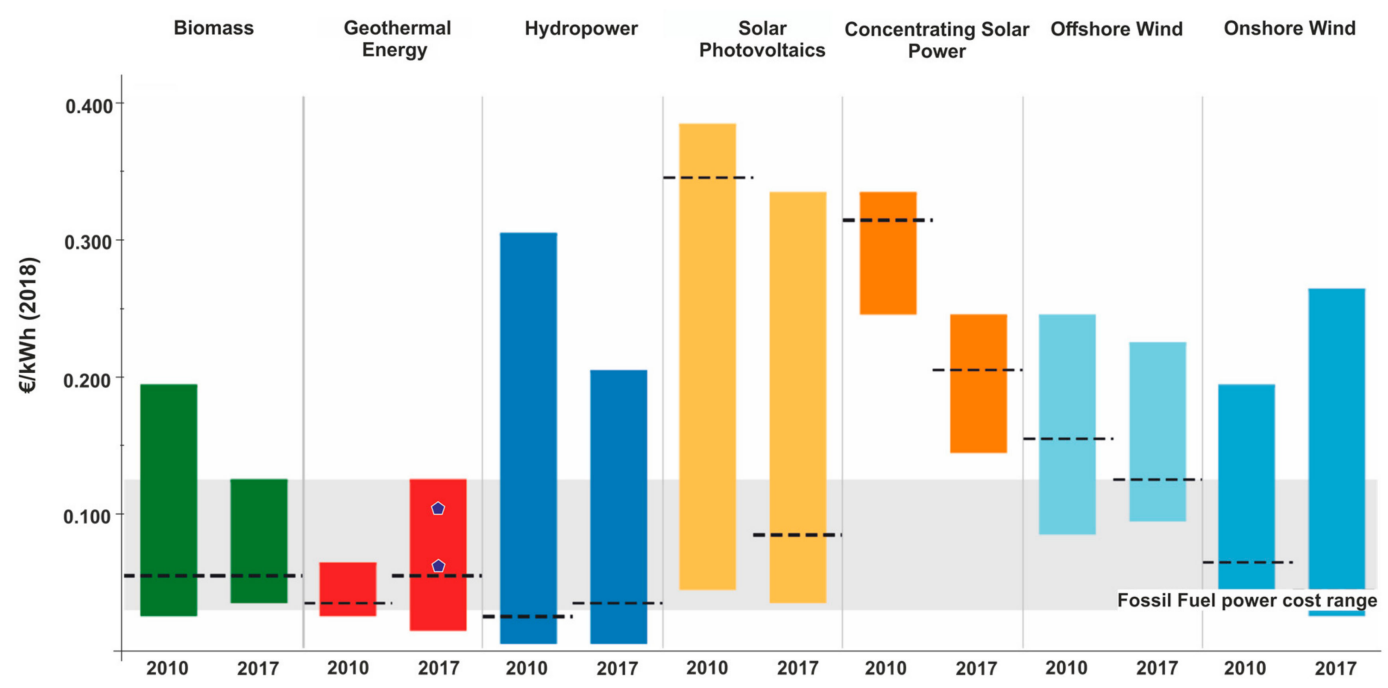

Figure 9. Levelized cost of electricity change from 2010 to 2017 for biomass, geothermal, hydropower, solar PV, concentrating solar power, offshore and onshore wind energy. Case 1 and case 2 is in the range of the assessed levels of LCOE for geothermal energy. Reproduced from IRENA 2018. [100].

While other renewable energy systems are comparable in GHG emissions (Figure 10), geothermal energy offers an obvious and readily available integration into carbon capture and storage that other systems lack. The LCOE of the studied CPG system in Germany falls within the range shown on Figure 9. The increase in LCOE in case of the coal power plant correlates well with data from Ramezan et al. [45]. 
The amount of sequestered $\mathrm{CO}_{2}$ is calculated based on the reservoir area, thickness, porosity and $\mathrm{CO}_{2}$ characteristics at reservoir pressure and temperature $\left(30 \mathrm{MPa}, 130^{\circ} \mathrm{C}\right)$. The result gives a $29 \times 10^{6}$ tonnes $\mathrm{CO}_{2}$ sequestration potential over 20 years including the $5 \%$ natural non-recoverable fluid loss [22]. This value is converted to $\mathrm{g} / \mathrm{kWh}$ to compare the sequestration potential and global warming potential from LCA studies expressed in $\mathrm{CO}_{2}$ equivalents as $\mathrm{g} / \mathrm{kWh}$. Data and results from LCA studies are representative for current EGS power plants in Germany producing electricity $[12,13]$. Results and data for comparison are summarized on Figure 10. Additionally, the project has a potential to reduce the emission levels of the coal power plant from $750 \mathrm{~g} / \mathrm{kWh}$ ([43] reference value) to $585 \mathrm{~g} / \mathrm{kWh}$. Moreover, thermal energy is often viewed as a less valuable product but has interesting potentials considering advancing technologies. The amount of potential thermal energy in the geothermal power plant is 209,977 MWh/year. This thermal energy is present in the system regardless of the electricity generation. In Germany the average household consumption of thermal energy (heating and hot water) with a range of 6218-14,306 $\mathrm{kWh} /$ year (depending on the type of dwelling) was based on Routledge and Williams [29] for dwellings build after the year 2000. The cost of thermal energy was determined as $€ 0.04 / \mathrm{kWh}$. Compared to the present study the CPG system utilising a heat recovery efficiency of $55 \%$ could distribute energy at a price of $€ 0.028 / \mathrm{kWh}$. Based on the average electricity (7900 kWh) and thermal energy consumptions $(10,000 \mathrm{kWh})$ /household the CPG system could provide clean electricity and thermal energy for 6600 and 12,000 households, respectively. Considering land use change the average measured area required for binary cycle geothermal power plants in Germany is 4 acres $\left(16,000 \mathrm{~m}^{2}\right)$. The sequestration potential of this land area is $29 \times 10^{6}$ tons of $\mathrm{CO}_{2}$ over 20 years of project lifetime which translates as $988 \mathrm{t}$ carbon $/ \mathrm{m}^{2}$. This value was compared to results in Karjalainen [101] as well as Stinson and Freedman [102] where the authors have determined a maximum sequestration potential of $473 \mathrm{t}$ carbon/ha or $47.3 \mathrm{~kg}$ carbon $/ \mathrm{m}^{2}$ for Acadian mixed tolerant hardwood forests in Canada over a 200-year period. It is visible that the CPG system has order of magnitudes higher sequestration potential compared to a conventional forest land.

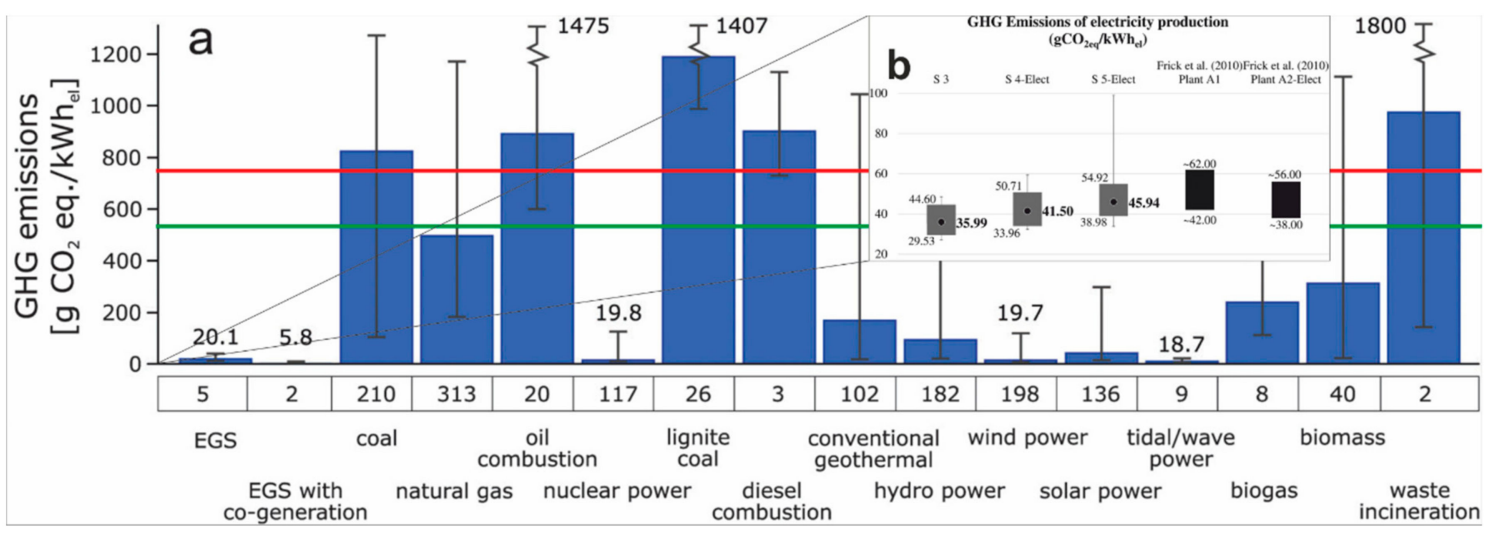

Figure 10. Global warming potential from LCA studies compared to emission levels and sequestration potential of the current project. Reference power plants are located in Germany in the Upper Rhine Graben working on Enhanced Geothermal Systems producing Combined Heat and Power. (a) The height of the bars and the numbers above them represents the arithmetic mean value of emissions. Numbers below each bar represents the number of estimates made during assessing the emission levels. Minimum and maximum values are visualised by the whiskers. (in [12]) A horizontal red line represents the average emissions from a coal power plant [43] while a green line is the value of the emission levels after $\mathrm{CO}_{2}$ sequestration. (b) global warming potential of selected EGS power plants producing electricity (in [13]) Values are expressed as $\mathrm{CO}_{2} \mathrm{~g} / \mathrm{kWh}$.

\section{Future Work and Considerations}

A deployment of any energy system depends on many factors, but reliability, efficiency and of course low carbon impact are among the critical requirements. For this reason, the research 
and development of novel technologies as well as supporting prototype projects is considered as an investment. The bladeless turbine was invented by Tesla as an alternative to conventional turbines [103]. Recent research also studied the operation of the turbine with a one-dimensional model analysis [40] and lab scale demonstration [41]. Data indicates elevated attributes to efficiency and capacity. A further research and a possible grant for the development and prototype production would be an added layer of interest for higher efficiency and productivity factors. The planning, engineering, prototype production is assumed as $€ 1.5 \times 10^{6}$ for a test phase device (equivalent to ca. $2.3 \%$ of total capital, or for an optimal system ca. $1.5 \%$ of net present costs). A loop from the main $\mathrm{CO}_{2}$ stream could be used to test the device under safe and controlled conditions. The excess thermal energy, or the energy that is not required for district heating could be utilized for agricultural purposes. Greenhouses are used widely in Netherlands, Spain, but in Eastern Europe as well [104,105]. Greenhouses are used as efficient facilities in agricultural production to decrease fresh water consumption and input requirements under controlled environment. Even research phase projects could be demonstrated. Algal photobioreactors are another possible candidate for such a project $[106,107]$. Base parameters are controlled, $\mathrm{CO}_{2}$ availability from power plants is adequate for algal growth and the bioproducts are environmentally friendly and compostable.

\section{Conclusions}

The objective of this paper was to investigate the feasibility of deploying the CPG technology in Germany. Renewable energy systems are currently being favoured and supported by the EU. Although, Geothermal energy is a mature technology it is represented with the least ratio among renewable sources. To promote geothermal energy a new approach was recommended where emerging and novel technologies facilitate the use of geothermal energy across a broader aerial scale. By utilising carbon dioxide and sequestering it from the environment the increasing rate of global warming can be mitigated. The pulverized coal power plant at Lünen (North Rhine Westhpalia, Germany) was taken as a reference for a modern state of the art coal power plant with possible integration of a post combustion capture technology. Pipeline transportation was assessed as the safest and most economical option for long term and transportation of large amounts of liquid carbon dioxide. Sandstone reservoirs are proved to be present in Northern Germany and the North Rhine Graben where geothermal energy is exploited with binary cycle technology. The CPG technology widens the possibilities as no initial geothermal fluid is required in the system. Carbon dioxide is pumped to the reservoir and the heat and energy is extracted at the production end of the system. The hydrocarbon industry with its well-established exploration, production and development background already using the $\mathrm{CO}_{2}$ injection technology for enhanced hydrocarbon recovery. Even with a relatively long pipeline distance reaching the North Sea and expanding the possibility of offshore $\mathrm{CO}_{2}$ storage the project could still be feasible. Given the impact that a material like carbon dioxide is having on the global environment it is imperative that the rates and volumes entering and exiting the ecosystem are managed. For a comparison if the sequestration potential of the CPG system was compared with natural indices like forests it would require $334 \mathrm{~km}^{2}$ land compared to the approximately $0.016 \mathrm{~km}^{2}$ occupied by the CPG geothermal power plant. In addition, the overall emissions during the life cycle of the project were considered as well. Values were converted to $\mathrm{g} / \mathrm{kWh}$ and compared with LCA studies of enhanced geothermal systems, fossil fuel and various renewable energy systems. Binary cycle geothermal energy or geothermal energy that is non-dependent on volcanic activity is among energy systems with the lowest overall life cycle impacts. Environmentally as well as economically the project was proved to be feasible. Legislations and incentives support the deployment of geothermal energy in Germany but at the same time projects have to be within limits of regulations. Geothermal energy is among the candidates of such a system where multiple localized geothermal power plants form a network either as localized centres or as a centralized system. In such a case the heat extraction rate could be controlled, and power plants could be temporarily shut down for a resting and recovery period [108]. In addition, the stored carbon dioxide can be viewed as a stock. Future developments of technologies 
could further utilise carbon dioxide in which case it could be recovered from the reservoir and reused. A carbon trading scheme in the EU is already in place [109], which creates opportunity for companies to trade $\mathrm{CO}_{2}$ emissions and hence indirectly decrease their greenhouse gas emissions.

Author Contributions: Data curation, L.M.; Investigation, K.M.; Methodology, L.M.; Software, L.M.; Supervision, K.M.; Writing-original draft, L.M.; Writing_review and editing, K.M., M.H. and F.M. All authors have read and agreed to the published version of the manuscript.

Funding: This research received no external funding.

Conflicts of Interest: The authors declare no conflict of interest.

\section{Nomenclature}

$\begin{array}{ll}\text { EGS } & \text { Enhanced geothermal system } \\ \mathrm{EOR} & \text { Enhanced oil recovery } \\ \mathrm{g} & \text { Grams } \\ \mathrm{IGCC} & \text { Integrated gasification combined cycle } \\ \mathrm{CO}_{2} & \text { Carbon dioxide } \\ \mathrm{CO}_{2} \text {-ECBM } & \text { Carbon dioxide enhanced coalbed methane } \\ \mathrm{CPG} & \text { Carbon dioxide plume geothermal } \\ \mathrm{kg} & \text { Kilograms } \\ \mathrm{km} & \text { Kilometre } \\ \mathrm{kW} & \text { Kilowatt } \\ \mathrm{kWh} & \text { Kilowatt hour } \\ \mathrm{LCA} & \text { Life cycle assessment } \\ \mathrm{LCOE} & \text { Levelized cost of electricity } \\ \mathrm{m} & \text { Meter } \\ \mathrm{MD} & \text { Measured depth } \\ \mathrm{MEA} & \text { Monoethanolamine } \\ \mathrm{MPa} & \text { Megapascal } \\ \mathrm{MW} & \text { Megawatt } \\ \mathrm{MW} & \text { Megawatt electricity } \\ \mathrm{MWh} & \text { Megawatt hour } \\ \mathrm{MW} \text { th } & \text { Megawatt thermal } \\ \mathrm{NGCC} & \text { Natural gas combined cycle } \\ \mathrm{P}_{\mathrm{cr}} & \text { Critical pressure } \\ \mathrm{ROI} & \text { Return on investment } \\ \mathrm{s} & \text { Second } \\ \mathrm{t} & \text { Metric tonnes } \\ \mathrm{T} & \text { Temperature } \\ \mathrm{T}_{\mathrm{cr}} & \text { Critical temperature } \\ \rho & \text { Density } \\ & \end{array}$

\section{References}

1. Directive 2012/27/EU of the European Parliament and of the Council of 25 October 2012 on Energy Efficiency, Amending Directives 2009/125/EC and 2010/30/EU and Repealing Directives 2004/8/EC and 2006/32/EC. Available online: http://eur-lex.europa.eu/legal-content/EN/TXT/PDF/?uri=CELEX:32012L0027\&from=EN (accessed on 10 March 2018).

2. EC 2030 Climate and Energy Policy Framework. Communication from the Commission to the European Parliament, the Council, the European Economic and Social Committee and the Committee of the RegionsA Policy Framework for Climate and Energy in the Period from 2020 to 2030. 2014. Available online: http://eur-lex.europa.eu/legal-content/EN/TXT/PDF/?uri=CELEX:52014DC0015\&-from=EN (accessed on 19 March 2018). 
3. German Federal Ministry for Economic Affairs and Energy (EEG). Renewable Energy Source Act. 2017. Available online: http://www.bmwi.de/Redaktion/EN/Downloads/rene-wable-energy-sources-act-2017.pdf? _blob=publicationFile\&v=3 (accessed on 22 March 2018).

4. Eurostat. Energy Balance Sheets European Commission-Eurostat. 2017. Available online: http://dx.doi.org/ 10.2785/032728 (accessed on 15 March 2018).

5. Matthes, F. Exit economics: The relatively low cost of Germany's nuclear phase-out. Bull. At. Sci. 2012, 68, 42-54. [CrossRef]

6. Kunz, F.; Weigt, H. Germany's Nuclear Phase Out: A Survey of the Impact since 2011 and Outlook to 2023. Econ. Energy Environ. Policy 2014, 3, 13-27. [CrossRef]

7. Larson, A. Trianel Coal Power Plant, Lünen, North Rhine - Westphalia. Power 2014, 158, 34-35.

8. IRENA (International Renewable Energy Agency). Final Renewable Energy Consumption (2016 Data). Available online: http://resourceirena.irena.org/gateway/dashboard/?topic=18\&subTopic=47 (accessed on 26 July 2018).

9. Mines, G.; Richard, C.; Nathwani, J.; Hanson, H.; Wood, R. Geothermal Plant Capacity Factors. In Proceedings of the Fortieth Workshop on Geothermal Reservoir Engineering, Stanford, CA, USA, 26-28 January 2015.

10. Sanyal, S.K. Cost of Geothermal Power and Factors that affect it. In Proceedings of the Twenty-Ninth Workshop on Geothermal Reservoir Engineering, Stanford, CA, USA, 26-28 January 2004.

11. Sanyal, S.K. Cost of Electric Power from Enhanced Geothermal Systems-Its Sensitivity and Optimization. Trans. Geotherm. Resour. Counc. 2009, 33, 221-225.

12. Menberg, K.; Pfister, S.; Blum, P.; Bayer, P. A matter of meters: State of the art in the life cycle assessment of enhanced geothermal systems. Energy Environ. Sci. 2016, 9, 2720. [CrossRef]

13. Pratiwi, A.; Ravier, G.; Genter, A. Life-cycle climate-change impact assessment of enhanced geothermal system plants in the Upper Rhine Valley. Geothermics 2018, 75, 26-39. [CrossRef]

14. Barbier, E. Geothermal energy technology and current status: An overview. Renew. Sustain. Energy Rev. 2002, 6, 3-65. [CrossRef]

15. Johnston, I.W.; Narsilio, G.A.; Colls, S. Emerging Geothermal Energy Technologies. KSCE J. Civ. Eng. 2011, 15, 643-653. [CrossRef]

16. Randolph, J.B.; Saar, M.O. Combining geothermal energy capture with geologic carbon dioxide sequestration. Geophys. Res. Lett. 2011, 38. [CrossRef]

17. IPCC. IPCC Special Report on Carbon Dioxide Capture and Storage; Prepared by Working Group III of the Intergovernmental Panel on Climate Change; Metz, B., Davidson, O., de Coninck, H.C., Loos, M., Meyer, L.A., Eds.; Cambridge University Press: Cambridge, UK; New York, NY, USA, 2005; 442p.

18. International Energy Agency (IEA). $\mathrm{CO}_{2}$ CAPTURE and STORAGE a Key Carbon Abatement Option. 2008. Available online: https://www.iea.org/publications/freepublications/publication/CCS_2008.pdf (accessed on 15 June 2018).

19. European Commission. Implementation of Directive 2009/31/EC on the Geological Storage of Carbon Dioxide. 2011. Available online: https://ec.europa.eu/clima/sites/clima/files/lowcarbon/ccs/implementation/docs/gd1_ en.pdf (accessed on 20 June 2018).

20. Randolph, J.B.; Saar, M.O. Coupling carbon dioxide sequestration with geothermal energy capture in naturally permeable, porous geologic formations: Implications for $\mathrm{CO}_{2}$ sequestration. Energy Procedia 2011, 4, 2206-2213. [CrossRef]

21. Garapati, N.; Randolph, J.B.; Valencia, J.L.; Saar, M.O. $\mathrm{CO}_{2}$-Plume Geothermal (CPG) Heat Extraction in Multi-layered Geologic Reservoirs. Energy Procedia 2014, 63, 7631-7643. [CrossRef]

22. Pruess, K. The TOUGH codes-a family of simulation tools for multiphase flow and transport processes in permeable media. Vadose Zone J. 2004, 3, 738-746. [CrossRef]

23. Pruess, K. Enhanced geothermal systems (EGS) using $\mathrm{CO}_{2}$ as working fluid-a novel approach for generating renewable energy with simultaneous sequestration of carbon. Geothermics 2008, 35, 351-367. [CrossRef]

24. Pioro, I.; Mokry, S. Thermophysical properties at critical and supercritical pressures. In Heat Transfer Theoretical Analysis, Experimental Investigations and Industrial Systems; Belmiloudi, A., Ed.; IntechOpen Ltd.: London UK, 28 January 2011; ISBN 978-953-307-226-5.

25. Zhang, F.Z.; Jiang, P.X.; Xu, R.N. System thermodynamic performance comparison of $\mathrm{CO}_{2}$-EGS and water-EGS systems. Appl. Therm. Eng. 2013, 61, 236-244. [CrossRef] 
26. Liu, J.; Suna, L.; Wub, X.; Yao, J. Feasibility of combination of $\mathrm{CO}_{2}$ geological storage with geothermal-type water-soluble gas recovery in Yinggehai Basin, China. Int. J. Greenh. Gas Control 2016, 45, 139-149. [CrossRef]

27. Seibt, P.; Kabus, F.; Hoth, P. The Neustadt-Glewe Geothermal Power Plant - Practical Experience in the Reinjection of Cooled Thermal Waters into Sandstone Aquifers. In Proceedings of the World Geothermal Congress, Antalya, Turkey, 24-29 April 2005.

28. Weber, J.; Ganz, B.; Schellschmidt, R.; Sanner, B.; Schulz, R. Geothermal Energy Use in Germany. In Proceedings of the World Geothermal Congress, Melbourne, Australia, 19-25 April 2015; Available online: https://pangea.stanford.edu/ERE/db/WGC/papers/WGC-/2015/-01045.pdf (accessed on 23 June 2018).

29. Routledge, K.; Williams, J. District heating - Heat metering Cost Benefit Analysis. Heat Strategy \& Policy Department of Energy and Climate Change, Building Research Establishment Ltd.; 2012. Available online: https://assets.publishing.service.gov.uk/government/uploads/system/uploads/attachment_data/file/ 48389/5462-district-heating--heat-metering-cost-benefit-anal.pdf (accessed on 30 July 2018).

30. Lüschen, E.; Wolfgramm, M.; Fritzer, T.; Dussel, M.; Thomas, R.; Schulz, R. 3D seismic survey explores geothermal targets for reservoir characterization at Unterhaching, Munich, Germany. Geothermics 2014, 50, 167-179. [CrossRef]

31. Homuth, S.; Gütz, A.E.; Sass, I. Reservoir characterization of the Upper Jurassic geothermal target formations (Molasse Basin, Germany): Role of thermofacies as exploration tool. Geother. Energy Sci. 2015, 3, 41-49. [CrossRef]

32. Aretz, A.; Bär, K.; Götz, A.E.; Sass, I. Outcrop analogue study of Permocarboniferous geothermal sandstone reservoir formations (northern Upper Rhine Graben, Germany): Impact of mineral content, depositional environment and diagenesis on petrophysical properties. Int. J. Earth Sci. (Geol. Rundsch) 2016, 105, 1431-1452. [CrossRef]

33. Van Alphen, K.; van Ruijven, J.; Kasa, S.; Hekkert, M.; Turkenburg, W. The performance of the Norwegian carbon dioxide, capture and storage innovation system. Energy Policy 2009, 37, 43-55. [CrossRef]

34. Leung, D.Y.C.; Caramanna, G.; Maroto-Valer, M.M. An overview of current status of carbon dioxide capture and storage technologies. Renew. Sustain. Energy Rev. 2014, 39, 426-443. [CrossRef]

35. Leach, A.; Mason, C.F.; van't Veld, K. Co-optimization of enhanced oil recovery and carbon sequestration. Resour. Energy Econ. 2011, 33, 893-912. [CrossRef]

36. Muggeridge, A.; Cockin, A.; Webb, K.; Frampton, H.; Collins, I.; Moulds, T.; Salino, P. Recovery rates, enhanced oil recovery and technological limits. Philos. Trans. Math. Phys. Eng. Sci. 2014, 372, 1-25. [CrossRef] [PubMed]

37. Godec, M.; Koperna, G.; Gale, J. $\mathrm{CO}_{2}$-ECBM: A Review of its Status and Global Potential. Energy Procedia 2014, 63, 5858-5869. [CrossRef]

38. Bachu, S.; Bonijoly, D.; Bradshaw, J.; Burrus, R.; Holloway, S.; Christensen, N.P.; Mathiassen, O.M. $\mathrm{CO}_{2}$ storage capacity estimation: Methodology and gaps. Int. J. Greenh. Gas Control 2007, 1, 430-443. [CrossRef]

39. Cheah, W.Y.; Ling, T.C.; Show, P.L.; Juan, J.C.; Chang, J.-S.; Lee, D.-J. Cultivation in wastewaters for energy: A microalgae platform. Appl. Energy 2016, 179, 609-625, ISSN 0306-2619. [CrossRef]

40. Song, J.; Ren, X.; Li, X.; Gu, C.; Zhang, M. One-dimensional model analysis and performance assessment of Tesla turbine. Appl. Therm. Eng. 2018, 134, 546-554. [CrossRef]

41. Manfrida, G.; Pacini, L.; Talluri, L. An upgraded Tesla turbine concept for ORC applications. Energy 2018, 158, 33-40. [CrossRef]

42. Olivier, J.G.J.; Janssens-Maenhout, G.; Muntean, M.; Peters, J.A.H.W. Trends in Global CO 2 Emissions: 2016 Report; PBL Netherlands Environmental Assessment Agency: The Hague, Netherlands, 2016; Available online: http://edgar.jrc.ec.europa.eu/news_docs/jrc-2016-trends-in-global-co2-emissions-2016-report-103425. pdf (accessed on 5 August 2019).

43. International Energy Agency (IEA). Power Generation from Coal Measuring and Reporting Efficiency Performance and $\mathrm{CO}_{2}$ Emissions s.n. S.1. 2010. Available online: https://www.iea.org/ciab/papers/power_ generation_from_coal.pdf (accessed on 15 June 2018).

44. D'Amore, F.; Bezzo, F. Economic optimisation of European supply chains for $\mathrm{CO}_{2}$ capture, transport and sequestration. Int. J. Greenh. Gas Control 2017, 65, 99-116.

45. Ramezan, M.; Skone, J.T.; Nsakala, Y.N.; Liljedahl, N.G. Carbon Dioxide Capture from Existing Coal-Fired Power Plants. Available online: https://www.globalccsinstitute.com/archive/hub/publications/159713/carbondioxide-capture-existing-coal-fired-power-plants.pdf (accessed on 15 December 2019). 
46. Liu, H.; Hou, Z.; Were, P.; Sun, X.; Gou, Y. Numerical studies on $\mathrm{CO}_{2}$ injection-brine extraction process in a low-medium temperature reservoir system. Environ. Earth Sci. 2015, 73, 6839-6854. [CrossRef]

47. Kemp, A.G.; Kasim, A.S. A Least-Cost Optimisation Model of $\mathrm{CO}_{2}$ Capture Applied to Major UK Power Plants Within The EU-ETS Framework. Energy J. 2008, 29, 99-134. [CrossRef]

48. Bayer, U.; Scheck, M.; Rabbel, W.; Krawczyk, C.M.; Götze, H.-J.; Stiller, M.; Beilecke, T.; Marotta, A.-M.; Barrio-Alvers, L.; Kuder, J. An integrated study of the NE German Basin. Tectonophysics 1999, 314, $285-307$. [CrossRef]

49. Becker, I.; Wüstefeld, P.; Koehrer, B.; Felder, M.; Hilgers, C. Porosity and Permeability variations in a tight gas sandstone reservoir analogue, Westphalian D, Lower Saxony Basin, NW Germany: Influence of Depositional setting and diagenesis. J. Pet. Geol. 2017, 40, 363-390. [CrossRef]

50. Von Pasternak, M. Exploration and production of crude oil and natural gas in Germany in 2011. Erdöl Erdgas Kohle 2012, 129, 260-273.

51. Desbois, G.; Urai, J.L.; Hemes, S.; Schröppel, B.; Schwarz, J.-O.; Mac, M.; Weiel, D. Multi-scale analysis of porosity in diagenetically altered reservoir sandstone from the Permian Rotliegend (Germany). J. Pet. Sci. Eng. 2016, 140, 128-148. [CrossRef]

52. Schill, E.; Genter, A.; Cuenot, N.; Kohl, T. Hydraulic performance history at the Soultz EGS reservoirs from stimulation and long-term circulation tests. Geothermics 2017, 70, 110-124. [CrossRef]

53. Busch, A.; Bertier, P.; Gensterblum, Y.; Rother, G.; Spiers, C.J.; Zhang, M.; Wentinck, H.M. On sorption and swelling of $\mathrm{CO}_{2}$ in clays. Geomech. Geophys. Geo-Energy Geo-Resour. 2016, 2, 111-130. [CrossRef]

54. Markewitz, P.; Kuckshinrichs, W.; Leitner, W.; Linssen, J.; Zapp, P.; Bongartz, R.; Schreiber, A.; Müller, T.E. Worldwide innovations in the development of carbon capture technologies and the utilization of $\mathrm{CO}_{2}$. Energy Environ. Sci. 2012, 5, 7281. [CrossRef]

55. Goeppert, A.; Czaun, M.; Prakash, S.G.K.; Olah, G.A. Air as the renewable carbon source of the future: An overview of $\mathrm{CO}_{2}$ capture from the atmosphere. Energy Environ. Sci. 2012, 5, 7833. [CrossRef]

56. Vasterling, M.; Wegler, U.; Becker, J.; Brüstle, A.; Bischoff, M. Real-time envelope cross-correlation detector: Application to induced seismicity in the Insheim and Landau deep geothermal reservoirs. J. Seismol. 2017, 21, 193-208. [CrossRef]

57. Barth, A. Die Erdbeben in Kandel/S“udpfalz von 1880 und 1903. Bautechnik 2011, 88, 860-865. (In German) [CrossRef]

58. Legarth, B.; Tischner, T.; Huenges, E. Stimulation experiments in sedimentary, low-enthalpy reservoirs for geothermal power generation, Germany. Geothermics 2003, 32, 487-495. [CrossRef]

59. Noack, V.; Cherubini, Y.; Scheck-Wenderoth, M.; Lewerenz, B.; Höding, T.; Simon, A.; Moeck, I. Assessment of the present-day thermal field (NE German Basin)_-Inferences from 3D modelling. Chem. Erde 2010, 70, 47-62. [CrossRef]

60. Müller, C.; Siegesmund, S.; Blum, P. Evaluation of the representative elementary volume (REV) of a fractured geothermal sandstone reservoir. Environ. Earth Sci. 2010, 61, 1713-1724. [CrossRef]

61. Govindan, R.; Elahi, N.; Korre, A.; Durucan, S.; Hanstock, D. A Statistical Learning Approach to Model the Uncertainties in Reservoir Quality for the Assessment of $\mathrm{CO}_{2}$ Storage Performance in the Lower Permian Rotliegend Group in the Mid North Sea High Area. Energy Procedia 2017, 114, 4637-4642. [CrossRef]

62. Feather, B.; Archer, R.A. Enhanced Gas Recovery by Carbon Dioxide Injection for Storage Purposes. In Proceedings of the 17th Australian Fluid Mechanics Conference, Auckland, New Zealand, 5-9 December 2010.

63. Khan, C.; Amin, R.; Madden, G. Carbon dioxide injection for enhanced gas recovery and storage (reservoir simulation). Egypt. J. Pet. 2013, 22, 225-240. [CrossRef]

64. Germany Oil \& Gas Report Q1 2018; Business Monitor International (BMI), BMI Research: London, UK, 2017; ISSN 1748-3964.

65. Cziesla, F.; Bewerunge, J.; Senzel, A. Lünen State-of-the Art Ultra Supercritical Steam Power Plant Under Construction. In Proceedings of the SIEMENS, POWER-GEN Europe 2009, Cologne, Germany, 26-29 May 2009.

66. Umweltbundesamt. Kraftwerke und Verbundnetze in Deutschland, Stand März 2018, Energieversorgung und -daten, SG UBA-Grafik, GISU. 2018. Available online: https:/www.umweltbundesamt.de/sites/default/ files/medien/372/bilder/dateien/de_kraftwerkskarte.pdf (accessed on 17 June 2018). (In German). 
67. O'Sullivan, M.; Yeha, A.; Mannington, W. Renewability of geothermal resources. Geothermics 2010, 39, 314-320. [CrossRef]

68. Stefansson, V. Investment cost for geothermal power plants. Geothermics 2002, 31, 263-272. [CrossRef]

69. DiPippo, R. Geothermal powerplants: Evolution and performance assessments. Geothermics 2015, 53, $291-307$. [CrossRef]

70. Ziegler, P. Geodynamic model for alpine intra-plate compressional deformation in western and central Europe. In Inversion Tectonics; Cooper, M.A., Williams, G.D., Eds.; Special Publications; Geological Society, Blackwell Scientific Publications: London UK, 1989; Volume 44, pp. 63-85.

71. Betz, D.; Führer, F.; Greiner, G.; Plein, E. Evolution of the Lower Saxony Basin. Tectonophysics 1987, 137, 127-170. [CrossRef]

72. Ziegler, P. Geological Atlas of Western and Central Europe, 2nd ed.; Elsevier: Amsterdam, The Netherlands; Shell Internationale Petroleum Maatschappij BV: The Hague, The Netherlands, 1990; 232p.

73. Van Wees, J.-D.; Stephenson, R.; Ziegler, P.; Bayer, U.; McCann, T.; Dadlez, R.; Gaupp, R.; Narkiewicz, M.; Bitzer, F.; Scheck, M. On the origin of the Southern Permian Basin, Central Europe. Mar. Pet. Geol. 2000, 17, 43-59. [CrossRef]

74. Gast, R.; Gundlacht, T. Permian strike slip and extensional tectonics in Lower Saxony, Germany. Z. Dtsch. Ges. Für Geowiss. 2006, 157, 41-55. [CrossRef]

75. Binot, F.; Gerling, P.; Hiltmann, W.; Kockel, F.; Wehner, H. The petroleum system in the Lower Saxony Basin. In Generation, Accumulation and Production of Europe's Hydrocarbons III' EAPG; Spencer, A.M., Ed.; Special Publication; Springer: Berlin/Heidelberg, Germany, 1993; Volume 3, pp. 121-139.

76. Bruns, B.; Di Primio, R.; Berner, U.; Littke, R. Petroleum system evolution in the inverted Lower Saxony Basin, northwest Germany: A 3D basin modeling study. Geofluids 2013, 13, 246-271. [CrossRef]

77. Leeder, M.R.; Hardman, M. Carboniferous geology of the Southern North Sea Basin and controls on hydrocarbon prospectivity. In Tectonic Events Responsible for Britain's Oil and Gas Reserves; Hardman, R.P.F., Brooks, J., Eds.; Special Publications; Geological Society: London, UK, 1990; Volume 55, pp. 87-105.

78. Petmecky, S.; Meier, L.; Reiser, H.; Littke, R. High thermal maturity in the Lower Saxony Basin: Intrusion or deep burial? Tectonophysics 1999, 304, 317-344. [CrossRef]

79. Kombrink, H.; Besley, B.; Collinson, J.; den Hartog Jager, D.; Drozdzewski, G.; Dusar, M.; Hoth, P.; Pagnier, H.; Stemmerik, L.; Waksmundzka, M.; et al. Petroleum geological atlas of the Southern Permian Basin area. In Carboniferous; Doornenbal, J.C., Stevenson, A.G.S., Eds.; EAGE: Houten, The Netherlands, 2010; pp. 81-99.

80. Jones, N.S.; Glover, B.W. Fluvial sand body architecture, cyclicity and sequence stratigraphical setting -implications for hydrocarbon reservoirs: The Westphalian C and D of the Osnabrück-Ibbenbüren area, northwest Germany. In Carboniferous Hydrocarbon Geology, the Southern North Sea and Surrounding Onshore Areas; Collinson, J.D., Evans, D.J., Holliday, D.W., Jones, N.S., Eds.; Yorkshire Geological Society Occasional Publications: Yorkshire, UK, 2005; Volume 7, pp. 57-74.

81. Arndt, D.; Bär, K.; Fritsche, J.-G.; Kracht, M.; Sass, I.; Hoppe, A. 3D structural model of the Federal State of Hesse (Germany) for geo-potential evaluation. Z. Dt. Ges. Geowiss. 2011, 162, 353-370.

82. Agemar, T.; Schellschmidt, R.; Schulz, R. Subsurface temperature distribution in Germany. Geothermics 2012, 44, 65-77. [CrossRef]

83. Agemar, T.; Brunken, J.; Jodocy, M.; Schellschmidt, R.; Schulz, R.; Stober, I. Untergrundtemperaturen in Baden-Württemberg. Z. Dt. Ges. Geowiss. 2013, 164, 49-62. [CrossRef]

84. Saar, M.O.; Randolph, J.B.; Kuehn, T.H. Carbon Dioxide-Based Geothermal Energy Generation Systems and Methods Related Thereto. U.S. Patent US8,316,955 B2, 27 November 2012.

85. Saar, M.O.; Randolph, J.B.; Kuehn, T.H. Carbon Dioxide-Based Geothermal Energy Generation Systems and Methods Related Thereto. Europe Patent 2406562, 17 December 2014.

86. Jiang, P.X.; Zhang, F.Z.; Xu, R.N. Thermodynamic analysis of a solar-enhanced geothermal hybrid power plant using $\mathrm{CO}_{2}$ as working fluid. Appl. Ther. Eng. 2017, 116, 463-472. [CrossRef]

87. Stanger, R.; Wall, T.; Spörl, R.; Paneru, M.; Grathwohl, S.; Weidmann, M.; Scheffknecht, G.; McDonald, D.; Myöhänen, K.; Ritvanen, J.; et al. Oxyfuel combustion for $\mathrm{CO}_{2}$ capture in power plants. Int. J. Greenh. Gas Control 2015, 40, 55-125. [CrossRef]

88. Haumann, D.; Göttlicher, G.; Osmancevic, E.; Kuhn, T.; Konrad, C.; Strittmatter, J. CO 2 Pipeline Transport from Germany to Algeria. In Proceedings of the 7th Pipeline Technology Conference. ,Calgary, AB, Canada, 24-28 September 2012. 
89. Trianel Kohlekraftwerk Lünen GmbH \& Co. KG. Daten und Fakten zum Kraftwerk. 2017. Available online: http://www.trianel-luenen.de/kraftwerk/daten-und-fakten/ (accessed on 15 June 2018). (In German).

90. Heddle, G.; Herzog, H.; Klett, M. The Economics of $\mathrm{CO}_{2}$ Storage; Laboratory of Energy and the Environment, Massachusetts Institute of Technology: Cambridge, MA, USA, 2003; 111p.

91. Morbee, J.; Serpa, J.; Tzimas, E. Optimised deployment of a European $\mathrm{CO}_{2}$ transport network. Int. J. Greenh. Gas Control 2012, 7, 48-61. [CrossRef]

92. IEAGHG. $\mathrm{CO}_{2}$ Pipeline Infrastructure. 2013. Available online: https://ieaghg.org/docs/General_Docs/ Reports/2013-18.pdf (accessed on 21 July 2018).

93. Adams, B.M.; Kuehn, T.H.; Randolph, J.B.; Saar, M.O. The Reduced Pumping Power Requirements from Increasing the Injection Well Fluid Density. Geotherm. Resour. Counc. Trans. 2012, 37, 667-672.

94. Ebeling, J.C.; Luo, X.; Kabelac, S.; Luckmann, S.; Kruse, H. Dynamic simulation and experimental validation of a two-phase closed thermosyphon for geothermal application. Propuls. Power Res. 2017, 6, 107-116. [CrossRef]

95. Kipsang, C. Cost Model for Geothermal Wells. In Proceedings of the World Geothermal Congress, Melbourne, Australia, 19-25 April 2015.

96. Lukawski, M.Z.; Anderson, B.J.; Augustine, C.; Capuano, L.E., Jr.; Beckers, K.F.; Livesay, B.; Tester, J.W. Cost analysis of oil, gas, and geothermal well drilling. J. Pet. Sci. Eng. 2014, 118, 1-14. [CrossRef]

97. Wang, F.; Deng, S.; Zhao, J.; Zhao, J.; Yang, G.; An, J. Integrating geothermal into coal-fired power plant with carbon capture: A comparative study with solar energy. Energy Convers. Manag. 2017, 148, 569-582. [CrossRef]

98. Clauser, C.; Ewert, M. The renewables cost challenge: Levelized cost of geothermal electric energy compared to other sources of primary energy - Review and case study. Renew. Sustain. Energy Rev. 2018, 82, 3683-3693. [CrossRef]

99. Directive 2011/92/EU of the European Parliament and of the Council of 13 December 2011 on the Assessment of the Effects of Certain Public and Private Projects on the Environment Text with EEA Relevance. Available online: http://data.europa.eu/eli/dir/2011/92/oj (accessed on 18 November 2018).

100. IRENA. Renewable Power Generation Costs in 2018; International Renewable Energy Agency (IRENA): Abu Dhabi, UAE, 2017; Available online: http://www.irena.org/-/media/Files/IRENA/Agency/Publication/2018/ Jan/IRENA_2017_Power_Costs_2018.pdf (accessed on 26 July 2018)ISBN 978-92-9260-040-2.

101. Karjalainen, $\mathrm{T}$. The carbon sequestration potential of unmanaged forest stands in Finland under changing climatic conditions. Biomass Bioenergy 1996, 10, 313-329. [CrossRef]

102. Stinson, G.; Freedman, B. Potential for carbon sequestration in Canadian forests and agroecosystems. Mitig. Adapt. Strateg. Glob. Chang. 2001, 6, 1-23. [CrossRef]

103. Tesla, N. Tesla Patent Turbine. United States Patent Office, Serial No. 603,049. United States Patent 1,061,206, 17 January 1911. Available online: https://teslauniverse.com/nikola-tesla/patents/us-patent-1061206-turbine (accessed on 25 July 2018).

104. Van der Veen, R.A.C.; Kasmire, J. Combined heat and power in Dutch greenhouses: A case study of technology diffusion. Energy Policy 2015, 87, 8-16, ISSN 0301-4215. [CrossRef]

105. Specht, K.; Siebert, R.; Thomaier, S. Perception and acceptance of agricultural production in and on urban buildings (ZFarming): A qualitative study from Berlin, Germany. Agric. Hum. Values 2016, 33, 753-769.

106. Yan, C.; Zhu, L.; Wang, Y. Photosynthetic $\mathrm{CO}_{2}$ uptake by microalgae for biogas upgrading and simultaneously biogas slurry decontamination by using of microalgae photobioreactor under various light wavelengths, light intensities, and photoperiods. Appl. Energy 2016, 178, 9-18, ISSN 0306-2619. [CrossRef]

107. Ribeiro, R.L.L.; Vargas, J.V.C.; Mariano, A.B.; Ordonez, J.C. The experimental validation of a large-scale compact tubular microalgae photobioreactor model. Energy Res. 2017, 41, 2221-2235. [CrossRef]

108. Cook, D.; Davidsdottir, B.; Petursson, J.G. Accounting for the utilization of geothermal energy resources within the genuine progress indicator-A methodological review. Renew. Sustain. Energy Rev. 2015, 49, 211-220. [CrossRef]

109. Directive 2003/87/EC of the European Parliament and of the Council of 13 October 2003 Establishing a Scheme for Greenhouse Gas Emission Allowance Trading within the Community and Amending Council Directive 96/61/EC. Available online: http://data.europa.eu/eli/dir/2003/87/oj (accessed on 16 August 2018).

(C) 2020 by the authors. Licensee MDPI, Basel, Switzerland. This article is an open access article distributed under the terms and conditions of the Creative Commons Attribution (CC BY) license (http://creativecommons.org/licenses/by/4.0/). 